\title{
Meta-analysis of coagulation disbalances in COVID-19: 41 studies and 17601 patients
}

1 Polina Len ${ }^{1}$, Gaukhar Iskakova,"\#, Zarina Sautbayeva,\#, Aigul 2 Kussanova ${ }^{1,2, \#, \text { Ainur T. Tauekelova }}{ }^{3}$, Madina M. Sugralimova ${ }^{3}$, Anar S. 3 Dautbaeva ${ }^{3}$, Meruert M. Abdieva ${ }^{3}$, Eugene D. Ponomarev ${ }^{4}$, Alexander 4 Tikhonov $^{1}$, Makhabbat S. Bekbossynova ${ }^{3, *}$, Natasha S. Barteneva ${ }^{1,5,6^{*}}$

$5{ }^{1}$ School of Sciences and Humanities, Nazarbayev University, Nur-Sultan, Kazakhstan

$6 \quad{ }^{2}$ Core Facilities, Nazarbayev University, Nur-Sultan, Kazakhstan

$7 \quad{ }^{3}$ National Research Center for Cardiac Surgery, Nur-Sultan, Kazakhstan

$8{ }^{4}$ School of Biomedical Sciences, Chinese University of Hong Kong, Shatin. Hong Kong

$9 \quad{ }^{5}$ National Laboratory Astana, Nur-Sultan, Kazakhstan

$10{ }^{6}$ Brigham and Women's Hospital, Harvard Medical School, Boston, USA

11 \#These authors made an equal contribution in the study

$12 *$ Joint senior authors

13

14 Keywords: COVID-19; coagulopathy; thrombosis; D-dimers; platelets; fibrinogen; immature 15 reticulated platelets; prothrombin time 


\section{Abstract}

18 Introduction. Coagulation parameters are important determinants for COVID-19 infection.

19 We conducted meta-analysis to assess the early hemostatic parameters in retrospective 20 studies in association with severity of infection.

21 Methods. Ovid, PubMed, Web of Sciences, and Google Scholar were searched for research 22 articles that addressed clinical characteristics of COVID-19 patients and disease severity.

23 Results were filtered using exclusion and inclusion criteria and then pooled into a meta24 analysis to estimate the standardized mean difference with 95\% CI for each of five coagulation parameters (D-dimers, fibrinogen, prothrombin time, platelets count, activated partial thromboplastin time). Two authors independently extracted data and assessed study

27 quality. To explore the heterogeneity and robustness of our fundings, sensitivity and 28 subgroup analyses were conducted. Publication bias was assessed with contour-enhanced 29 funnel plots and Egger test by linear regression.

30 Results. Overall, 41 original studies (17601 patients) on SARS-CoV2 were included. For the 31 two groups of patients, stratified by severity, we identified that D-dimers, fibrinogen, 32 activated partial thromboplastin time, and prothrombin time were significantly higher in the severe group (SMD 0.6985 with 95\%CI [0.5155; 0.8815]); SMD 0.661with 95\%CI [0.3387;

34 0.9833]; SMD 0.2683 with 95\%CI [0.1357; 0.4009]; SMD 0.284 with 95\%CI [0.1472;

35 0.4208]). In contrast, PLT was significantly lower in patients with more severe cases of 36 COVID-19 (SMD -0.1684 with 95\%CI [-0.2826; -0.0542]). Neither the analysis by the leave-

37 one-out method nor the influence diagnostic have identified studies that solely cause 38 significant change in the effect size estimates. Subgroup analysis showed no significant 39 difference between articles originated from different countries but revealed that severity 40 assessment criteria might have influence over estimated effect sizes for platelets and D- 
41 dimers. Contour-enhanced funnel plots and the Egger test for D-dimers and fibrinogen

42 revealed significant asymmetry that might be a sign of publication bias.

43 Conclusions. The standard coagulation laboratory parameters with exception of platelets

44 counts are significantly elevated in patients with severe COVID-19. However, fibrinolysis

45 shutdown requires evaluation outside conventional coagulation tests and analysis of 46 additional specific markers related to clotting formation and PLT characteristics. We

47 hypothesize that a proportion and parameters of immature reticulated platelets may serve as 48 additional biomarkers for prediction of adverse events. 
medRxiv preprint doi: https://doi.org/10.1101/2021.10.17.21265108; this version posted October 18, 2021. The copyright holder for this preprint

\section{Introduction}

68 In less than two years of the outbreak, the COVID-19 pandemic took almost five million

69 lives (John Hopkins, 2021). SARS-CoV-2 is the seventh member of the large coronavirus

70 family capable of inducing human disease (Carsana et al., 2020). Viral respiratory infections,

71 including severe respiratory acute syndrome coronavirus (SARS-CoV), Middle East

72 respiratory syndrome coronavirus (MERS-CoV), SARS-CoV-2 may induce coagulopathy

73 and lead to intravascular thrombi and deposition of fibrinogen (Hwang et al., 2005; Yang et

74 al., 2005; Goeijenbier et al., 2012; WHO MERS guidelines, 2013; Giannis et al., 2020).

75 The coagulation system is activated and dysregulated during COVID-19 infection; however,

76 characteristics of COVID-19 associated coagulopathy are different from coagulation

77 disorders (Iba et al., 2020). Evidence of abnormal COVID-19-associated coagulation

78 parameters appeared already in early publications from Wuhan (Chen et al., 2020; Wang et

79 al., 2020; Zhou et al., 2020) and was supported by further publications worldwide (rev. Levi

80 et al., 2020; Iba et al., 2020). The reported hemostatic abnormalities with COVID-19

81 infection include increased D-dimers levels (Lippi et al., 2020; Demelo-Rodriguez et al.,

82 2020), fibrinogen levels (Ranucci et al., 2020; Panigada et al., 2020), changes in the

83 quantities and levels of activation of platelets (Yang et al., 2020; Lippi et al., 2020; Hottz et

84 al., 2020; Althaus et al., 2021), elevated von Willebrand factor (Goshua et al., 2020;

85 Doevelaar et al., 2021, rev. by Becker et al., 2021) and other coagulation parameters.

86 Persistently elevated thrombocytic events, even with initiation of prophylactic anti-

87 coagulation, suggest the presence of hypofibrinolysis in addition to detected

88 hypercoagulability in COVID-19 (Creel-Bulos et al., 2021; Bachler et al., 2021). It is also

89 consistent with results of thromboelastography (TEG) reported by Wright et al. (2020).

90 There is a need in early detection of elevated coagulation biomarkers to optimize risk

91 stratification of patients with COVID-19. However, due to limitations of early pandemic 
research with small study sizes and highly heterogeneous datasets it is still debated. The aim of the current study was to evaluate the validity of stratification based on early coagulation parameters provided by different clinical studies worldwide. We also aimed to use subgroup analysis to explore whether heterogeneity in results was in part explained by differences in patient subpopulations. Finally, the coagulation parameters of our own cohort were included in a systematic meta-analysis of published studies.

\section{Materials and Methods}

In this study, we aimed to identify the relationship between coagulation biomarkers taken at admission and severity of COVID-19 in adult (>18) patients by estimating the effect size of five laboratory coagulation tests: D-dimers, platelets, fibrinogen, activated partial thromboplastin time, and prothrombin time.

\subsection{Search Strategy, Exclusion and Inclusion criteria}

To broaden our search, we included Ovid, PubMed, Web of Sciences, and Google Scholar in the study. They were thoroughly scanned using the following keywords: SARS-CoV-2, COVID-19, coagulation, severity, characteristics, features, D-dimers, platelets, fibrinogen, cohort, observational, retrospective. First, satisfying search results were exported to an Excel table and duplicates were eliminated. Second, we conducted a preliminary review of retrieved articles' abstracts. Papers that focused on pregnant women, children, or specific age groups were avoided. Similarly, works that focused on the effect of medical treatment or patients with particular commodities were not included in the meta-analysis. We also excluded studies that compared mortality among groups of COVID-19 patients. Then, each publication was checked according to the inclusion criteria: sample size, severity assessment criteria, presence of at least one coagulation marker of interest expressed as a continuous variable. To be included, a study should have had more than 15 patients and divided them according to the 
medRxiv preprint doi: https://doi.org/10.1101/2021.10.17.21265108; this version posted October 18, 2021. The copyright holder for this preprint (which was not certified by peer review) is the author/funder, who has granted medRxiv a license to display the preprint in perpetuity.

It is made available under a CC-BY-NC-ND 4.0 International license .

disease severity - WHO guidelines, ICU admission, disease aggravation, or need for oxygen therapy. Next, a list of biomarkers should have included at least some of the coagulation parameters: platelets count (PLT), D-dimers (DD), fibrinogen (FIB), activated partial thromboplastin time (APTT), prothrombin time (PT), thrombin time (TT), Activated thrombin (AT), Factor VIII (FVIII), and Von Willebrand factor (vWF). Finally, the quality of selected articles was assessed with the NIH Quality Assessment Tool for Observational Cohort and Cross-Sectional studies. Questions 5, 6, 12, 13 were not applicable to selected studies due to their observational/retrospective nature; Question 8 was not applicable to studies with dichotomous exposure values, like ICU admission and need for oxygen therapy. Hence, studies with a quality score of less than five were excluded from the analysis. Search, and quality check were conducted independently by two authors. Disagreements were resolved during a joint discussion with a third author.

\subsection{Data extraction}

The primary goal was to retrieve from each article data about two groups of patients differing by disease severity: group size, stratification criteria, results of the laboratory tests. Apart from these, we kept a record of the country, hospital, and admission time in order to identify and exclude duplicate patients.

\subsection{Cohort from the National Research Center for Cardiac Surgery}

\subsubsection{Participants and data collection}

From a large cohort of 560 patients consecutively admitted from June 2020 to August 2021 due to coronavirus infection to the cardiology department of the NCJSC "National Research Center for Cardiac Surgery" (NRCCS), Nur-Sultan, Kazakhstan, we selected 451 patients with a confirmed diagnosis of COVID-19, aged $\geq 18$ years, and those with the onset of the disease $\leq 21$ days, all of whom were hospitalized for at least 24 hours with COVID-19. All 
demographic, clinical, laboratory data were extracted from the electronic records of the NRCSC. Laboratory tests included PLT, PT, international normalized ratio, APTT, FIB, DD. Blood samples were collected at admission by the clinical team. Clotting tests were performed according to standard methods. For coagulation tests (PT, international normalized ratio, APTT, FIB), we used AVATUBE® with sodium citrate, and it was measured on Sysmex CS-2500 (Sysmex, Japan). Blood for DD was collected in AVATUBE® with sodium citrate, and D-dimers were quantified on Cobas ${ }^{\circledR}$ 6000. PLT counts were measured on Sysmex XS-500 (Sysmex, Japan) with blood collection performed in AVATUBE® with K2 EDTA. The confirmation of SARS-CoV-2 infection was done by real-time quantitative reverse-transcription polymerase chain reaction (RT-PCR) assay on nose/throat swab or sputum samples using CFX96® Real-Time System (Bio-Rad Laboratories, Inc., USA).

\subsubsection{Clinical assessment}

The COVID-19 population was initially divided into four groups according to disease severity following local guidelines "Diagnosis and treatment of Covid-19 in Adults" (http://www.rcrz.kz/index.php/ru/2017-03-12-10-51-13/klinicheskie-protokoly) (Suppl. File 1). The study protocol was approved by the medical ethics committee of the National Research Center for Cardiac Surgery, Nur-Sultan, Kazakhstan waiving the need for written informed consent due to the retrospective design.

\subsection{Data analysis}

\subsubsection{Data transformation}

All data analysis was performed in the RStudio 1.4.1717 with $\mathrm{R}$ version 4.1.0 (Integrated Development Environment for R. RStudio, PBC, USA). In the most of cases, results were reported as the first, second (median), and third quartiles, reflecting that original data was not normally distributed. The "estmeansd" package was used to convert median, interquartile range, minimum and maximum values to mean and standard deviation. The package 
medRxiv preprint doi: https://doi.org/10.1101/2021.10.17.21265108; this version posted October 18, 2021. The copyright holder for this preprint (which was not certified by peer review) is the author/funder, who has granted medRxiv a license to display the preprint in perpetuity.

It is made available under a CC-BY-NC-ND 4.0 International license .

implements Box Cox transformation to normalize raw data prior to conversion. Then, Lou (2018) formulas for mean and Wan (2014) formulas for standard deviation are used. Since the criteria and number of groups differed from study to study, patients had to be regrouped into the more and less severe groups accordingly: severe/critical and mild/moderate, ICU admitted patients and outpatients/general ward patients, observed aggravation and recovery/stable, and need for oxygen therapy.

\subsubsection{Meta-analysis}

The "meta" and "metafor" packages were used for the meta-analysis. Heterogeneity was assessed using the $\mathrm{I}^{2}$, tau-squared, and prediction intervals. Following the recommendations of Veroniki (2016), Paule-Mandel (PM) tau-squared estimator and Q-Profile (QP) tausquared confidence interval estimator were used in this meta-analysis. To account for different measurement scales and possible inaccuracy of the Graph Digitizer, the standardized mean difference (SMD), or Hedges g, based on the inverse-variance approach, was estimated. For datasets with high heterogeneity, the Knapp-Hartung adjusted random-effects model is implemented. In case of low heterogeneity, the fixed-effects model is applied.

\subsubsection{Sensitivity and Subgroup analysis}

We also performed several sensitivity analyses using the "dmetar" package. First, we recalculated the effect size using the leave-one-out method. Second, basic outliers, studies whose confidence intervals do not overlap with the pooled effect confidence interval, were removed. Third, we ran the diagnostic for influential cases with Graphic Display of Study Heterogeneity (GOSH) plots and excluded them from the meta-analysis. To further explore the heterogeneity of the data, we conducted subgroup analyses: based on grouping criteria and location.

\subsection{Publication Bias}


medRxiv preprint doi: https://doi.org/10.1101/2021.10.17.21265108; this version posted October 18, 2021. The copyright holder for this preprint (which was not certified by peer review) is the author/funder, who has granted medRxiv a license to display the preprint in perpetuity.

It is made available under a CC-BY-NC-ND 4.0 International license . the possibility for publication bias in selected studies.

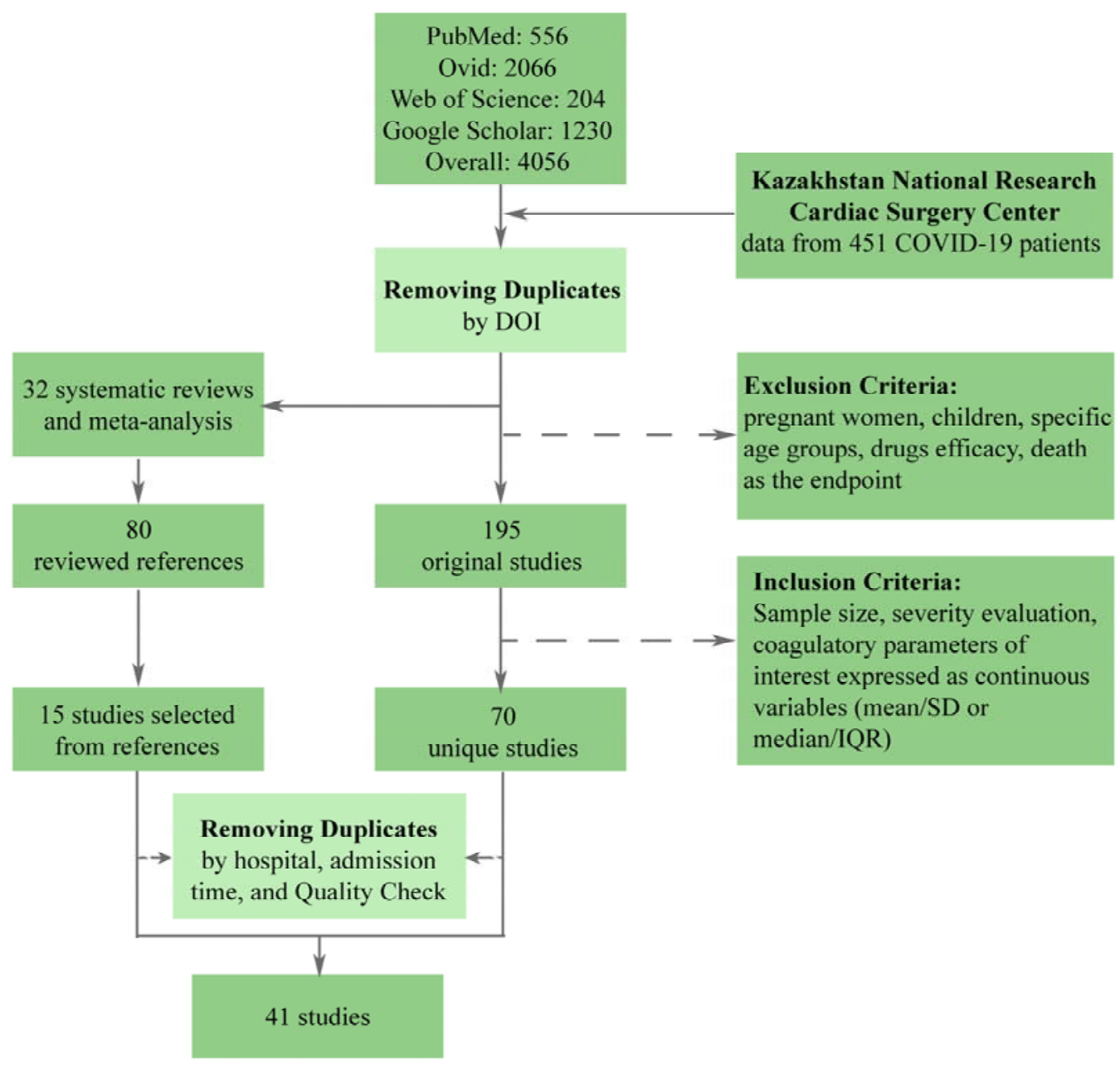

192 Figure 1. Flow diagram illustrating the process of data collection.

\section{Results}

\subsection{Results of the Web Search}

196 The stepwise process of selection is depicted in Figure 1. Initially, there were 4056 papers that matched search parameters. After the removal of duplicates and studies that did not meet the exclusion criteria, only 195 unique studies remained. A more thorough review based on the inclusion criteria has proven 125 studies to be unfitting. In addition to 70 that were left, 
medRxiv preprint doi: https://doi.org/10.1101/2021.10.17.21265108; this version posted October 18, 2021. The copyright holder for this preprint (which was not certified by peer review) is the author/funder, who has granted medRxiv a license to display the preprint in perpetuity.

It is made available under a CC-BY-NC-ND 4.0 International license .

200

201

202

203

15 studies were extracted from the references lists of previously published meta-analyses and systematic reviews. Finally, we performed a quality check and removed duplicate patients, which resulted in 40 being included into the meta-analysis. Besides original articles, we have included data from the National Research Center for Cardiac Surgery located in Nur-Sultan, Kazakhstan. This data set included data from 451 patients with acute COVID-19.

\subsection{Description of Selected Studies}

Overall, this meta-analysis comprises 17601 patients from 40 research papers and the NRCSC. Of the total, 24 studies originated from China, while the rest included data from France, Germany, Italy, Mexico, Singapore, South Korea, Turkey, UK, and the USA. Most of the articles (23) reported division of patients according to the WHO guidelines. Out of the rest, 12 articles made groups based on the ICU admission, 3 focused on disease aggravation, and 3 on the need for oxygen therapy. This information is depicted in Figure 2 in more detail.
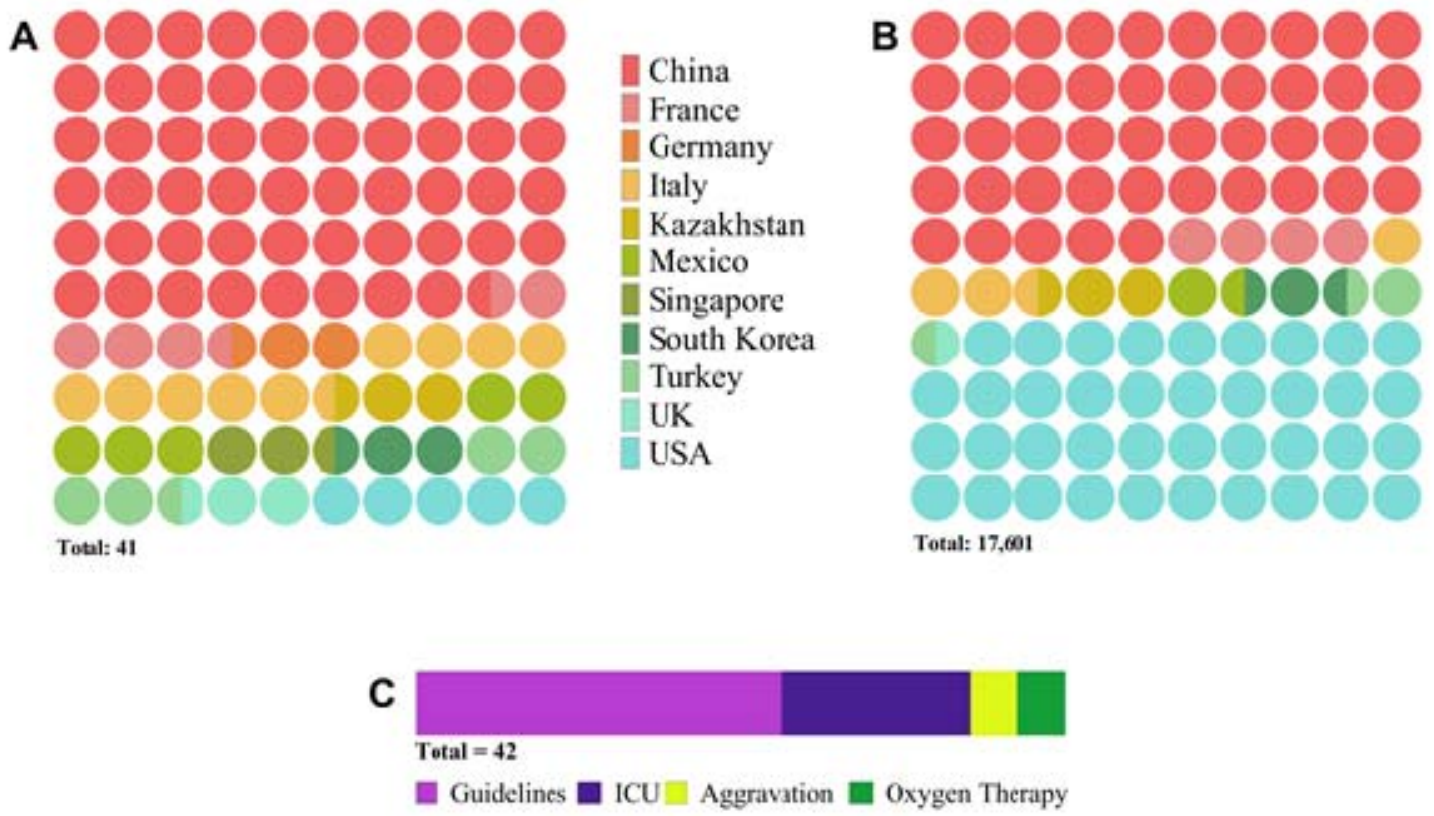
214 Figure 2. Diagram depicting characteristics of selected studies: (A) number of publications 215 per country, (B) number of patients per country, $(\mathbf{C})$ number of publications per severity 216 assessment criterion. The latter $(\mathbf{C})$ indicates the total number of research articles to be 42 217 instead of 41 because one study reported two populations of patients admitted to the hospital 218 at different periods.

\section{$219 \quad 3.3$ Results of Meta-analysis}

\subsubsection{Pooled Effect Sizes}

221 We collected data for five coagulation parameters: PLT, DD, FIB, APTT, and PT. In all 222 cases, the heterogeneity was extremely high $\left(\mathrm{I}^{2}>80 \%\right)$, so the Knapp-Hartung adjusted 223 random-effects model was applied in all parts of the meta-analysis. DD, FIB, APTT, and PT 224 were significantly higher in more severe cases (SMD 0.6985 with 95\%CI [0.5155; 0.8815]; 225 SMD 0.661 with 95\%CI [0.3387; 0.9833]; SMD 0.2683 with 95\%CI [0.1357; 0.4009]; SMD 2260.284 with 95\%CI [0.1472; 0.4208]). In contrast, PLT was significantly lower in patients 227 with severe cases of COVID-19 (SMD -0.1684 with 95\%CI [-0.2826; -0.0542]). Forest plots 228 for the meta-analyses are shown in Figures 3-4, and results are highlighted in Table 1. 
medRxiv preprint doi: https://doi.org/10.1101/2021.10.17.21265108; this version posted October 18, 2021. The copyright holder for this preprint

(which was not certified by peer review) is the author/funder, who has granted medRxiv a license to display the preprint in perpetuity.

\section{It is made available under a CC-BY-NC-ND 4.0 International license .}

\section{A Platelets}

\begin{tabular}{|c|c|c|c|c|c|c|}
\hline \multirow[b]{2}{*}{ Study } & \multirow[b]{2}{*}{ Total } & \multicolumn{3}{|c|}{ More Severe } & \multicolumn{2}{|c|}{ Less Severe } \\
\hline & & Mean & & Total & Mean & \\
\hline$X$ Zheng et al & 28 & 156.70 & 42.40 & 522 & 215.30 & 66.40 \\
\hline Nohet al & 26 & 182.76 & 70.07 & 2392 & 236.79 & 68.17 \\
\hline Bergantini et al & 10 & 183.70 & 62.00 & 142 & 278.00 & 156.00 \\
\hline Zhou et al & 28 & 157.50 & 23.00 & 95 & 184.00 & 42.00 \\
\hline Gerotziafas et al (1) & 102 & 204.48 & 59.65 & 2082 & 257.56 & 105.89 \\
\hline Jiao Liu et al & 261 & 170.77 & 88.94 & 8412 & 216.42 & 80.93 \\
\hline W Liu et al & 11 & 143.90 & 64.81 & 67 & 173.20 & 55.37 \\
\hline Jie Liu et al & 152 & 190.96 & 82.66 & 622 & 229.38 & 77.29 \\
\hline Shang et al & 139 & 200.97 & 83.38 & 304 & 239.28 & 91.51 \\
\hline$J$ Zhao et al & 84 & 163.20 & 34.84 & 499 & 186.55 & 57.79 \\
\hline P Wang et al & 18 & 227.51 & 52.10 & 1012 & 261.41 & 95.46 \\
\hline Ding et al & 30 & 166.17 & 66.88 & 281 & 189.66 & 63.73 \\
\hline G Zhang et al & 55 & 161.83 & 36.83 & 166 & 175.38 & 56.52 \\
\hline Cugno et al & 46 & 260.37 & 130.35 & 1023 & 307.13 & 207.68 \\
\hline Rauch et al & 71 & 214.00 & 98.00 & 1722 & 236.00 & 120.00 \\
\hline $\mathrm{N}$ Chen et al & 75 & 159.60 & 69.61 & 186 & 169.00 & 62.85 \\
\hline Higuera-de-la-Tijera et al & 27 & 219.70 & 73.10 & 1392 & 226.40 & 86.20 \\
\hline QChe & 43 & 213.18 & 99.61 & 102 & 217.45 & 60.77 \\
\hline Bauer et al & 7 & 199.38 & 43.15 & 102 & 202.30 & 64.27 \\
\hline Y Zhao et al & 74 & 253.02 & 122.61 & 2112 & 258.08 & 105.16 \\
\hline Young et al & 6 & 162.45 & 39.42 & 12 & 163.54 & 25.16 \\
\hline$J$ Zhang et al & 209 & 209.57 & 142.08 & 2522 & 213.11 & 82.79 \\
\hline$Z$ Chen et al & 43 & 222.08 & 123.54 & 1582 & 223.15 & 87.63 \\
\hline Mikami et al & 3708 & 224.77 & 88.25 & 2785 & 223.09 & 84.28 \\
\hline Gerotziafas et al (2) & 31 & 269.98 & 85.86 & 892 & 267.56 & 96.91 \\
\hline Lopez-Castaneda et al & 64 & 294.07 & 117.50 & 372 & 287.88 & 104.80 \\
\hline Yuet al & 864 & 247.43 & 105.70 & 7992 & 239.40 & 109.15 \\
\hline NRCSC & 110 & 227.44 & 116.70 & 3402 & 217.41 & 89.79 \\
\hline Liao et al & 231 & 216.64 & 161.71 & 149 & 197.82 & 2 73.47 \\
\hline Cen et al & 244 & 226.41 & 98.14 & 4092 & 211.93 & 80.73 \\
\hline Karakoyun et al & 84 & 264.79 & 146.01 & 1132 & 242.60 & 96.64 \\
\hline Bastug & 46 & 262.97 & 146.67 & 1452 & 240.94 & 107.66 \\
\hline H Zhang et a & 14 & 220.16 & 137.60 & 29 & 191.67 & 81.79 \\
\hline White et al & 75 & 288.00 & 138.00 & 342 & 221.00 & 87.00 \\
\hline $\begin{array}{l}\text { Random effects model } \\
\text { Prediction interval } \\
\text { Heterogeneity: } I^{2}=82 \%, \tau^{2}\end{array}$ & & & & 92 & & \\
\hline
\end{tabular}

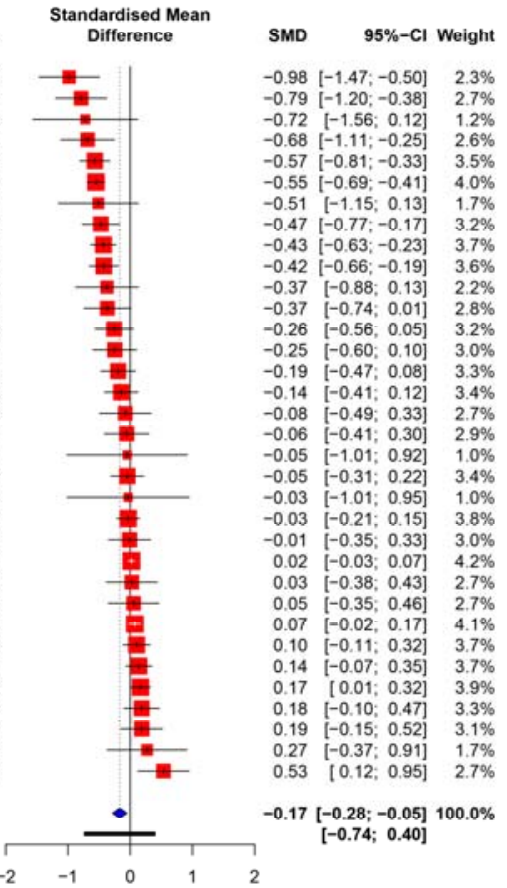

\section{B D-dimer}

\begin{tabular}{|c|c|c|c|c|c|c|c|c|c|c|}
\hline \multirow[b]{2}{*}{ Study } & \multirow[b]{2}{*}{ Total } & \multicolumn{3}{|c|}{ More Severe } & \multicolumn{2}{|c|}{ Less Severe } & \multirow{2}{*}{$\begin{array}{c}\text { Standardised Mean } \\
\text { Difference }\end{array}$} & \multirow[b]{2}{*}{ SMD } & \multirow[b]{2}{*}{$95 \%-\mathrm{Cl}$} & \multirow[b]{2}{*}{ Weight } \\
\hline & & Mean & SD & Total & Mean & SD & & & & \\
\hline Shang et al & 139 & 856.31 & 1008.98 & 304 & 2945.91 & 7518.31 & & -0.33 & {$[-0.54 ;-0.13]$} & $3.0 \%$ \\
\hline Bauer et al & 7 & 971.17 & 283.25 & 10 & 1132.30 & 563.65 & & -0.32 & {$[-1.30 ; 0.65]$} & $1.6 \%$ \\
\hline Fu et al & 16 & 1946.22 & 5627.75 & 59 & 2103.70 & 8107.84 & & -0.02 & {$[-0.57 ; 0.53]$} & $2.4 \%$ \\
\hline Rauch et al & 71 & 1432.83 & 1000.18 & 172 & 1400.20 & 1074.70 & & 0.03 & {$[-0.25 ; 0.31]$} & $2.9 \%$ \\
\hline Zhou et al & 28 & 370.00 & 150.00 & 95 & 300.00 & 460.00 & & 0.17 & {$[-0.25 ; 0.59]$} & $2.6 \%$ \\
\hline Gerotziafas et al (2) & 31 & 2487.64 & 932.44 & 89 & 2334.31 & 588.12 & & 0.22 & {$[-0.19 ; 0.63]$} & $2.6 \%$ \\
\hline Mikami et al & 3708 & 2513.10 & 2929.05 & 2785 & 1906.08 & 2426.98 & & 0.22 & {$[0.17 ; 0.27]$} & $3.1 \%$ \\
\hline Yuet al & 864 & 1541.71 & 2045.94 & 799 & 1089.75 & 1316.61 & & 0.26 & {$[0.16 ; 0.36]$} & $3.1 \%$ \\
\hline Micco et al & 31 & 980.44 & 738.19 & 54 & 773.91 & 668.09 & & 0.29 & {$[-0.15 ; 0.74]$} & $2.6 \%$ \\
\hline Long et al & 76 & 2546.32 & 5982.55 & 39 & 850.00 & 1680.00 & & 0.34 & {$[-0.05 ; 0.73]$} & $2.7 \%$ \\
\hline Cen et al & 244 & 3878.50 & 13263.42 & 409 & 873.72 & 1087.93 & & 0.37 & {$[0.21 ; 0.53]$} & $3.0 \%$ \\
\hline Q Chen et al & 43 & 395.56 & 272.95 & 102 & 307.62 & 219.61 & & 0.37 & {$[0.01 ; 0.73]$} & $2.7 \%$ \\
\hline Jiao Liu et al & 261 & 18837.21 & 97339.85 & 841 & 1158.83 & 1393.82 & & 0.37 & $0.23 ; 0.51]$ & $3.0 \%$ \\
\hline W Liu et al & 11. & 41945.80 & 280801.29 & 67 & 956.25 & 1583.88 & & 0.40 & {$[-0.24 ; 1.04]$} & $2.2 \%$ \\
\hline White et al & 75 & 2137.55 & 4624.70 & 34 & 462.17 & 442.55 & & 0.43 & {$[0.02 ; 0.84]$} & $2.6 \%$ \\
\hline Jie Liu et al & 152 & 11952.07 & 27966.64 & 62 & 1371.85 & 1736.96 & & 0.45 & {$[0.15 ; 0.74]$} & $2.8 \%$ \\
\hline$X$ Zheng et al & 28 & 165.80 & 128.10 & 52 & 102.10 & 102.10 & & 0.56 & {$[0.10 ; 1.03]$} & $2.5 \%$ \\
\hline Gerotziafas et al (1) & 102 & 2946.38 & 3114.77 & 208 & 1673.35 & 1600.76 & & 0.57 & {$[0.33 ; 0.81]$} & $2.9 \%$ \\
\hline Cugno et al & 46 & 6544.65 & 14441.02 & 102 & 1611.06 & 1829.37 & & 0.60 & {$[0.25 ; 0.96]$} & $2.7 \%$ \\
\hline Suleyman et al & 141 & 2642.85 & 3335.59 & 214 & 1258.73 & 1040.50 & & 0.61 & {$[0.40 ; 0.83]$} & $3.0 \%$ \\
\hline Lopez-Castaneda et al & 64 & 2840.00 & 3900.00 & 37 & 822.10 & 600.00 & & 0.64 & {$[0.22 ; 1.05]$} & $2.6 \%$ \\
\hline Y Zhao et al & 74 & 1318.16 & 2082.65 & 211 & 528.04 & 444.27 & & 0.70 & {$[0.43 ; 0.97]$} & $2.9 \%$ \\
\hline NRCSC & 109 & 2895.78 & 5469.52 & 339 & 609.53 & 967.84 & & 0.81 & {$[0.59 ; 1.03]$} & $2.9 \%$ \\
\hline G Zhang et al & 55 & 1256.45 & 2375.13 & 166 & 257.11 & 214.38 & & 0.83 & {$[0.52 ; 1.15]$} & $2.8 \%$ \\
\hline $\mathrm{H}$ Zhang et al & 14 & 7394.40 & 14416.61 & 29 & 375.81 & 225.80 & & 0.85 & {$[0.18 ; 1.51]$} & $2.1 \%$ \\
\hline N Chen et al & 75 & 842.00 & 1343.83 & 186 & 180.00 & 330.00 & & 0.86 & {$[0.58 ; 1.13]$} & $2.9 \%$ \\
\hline Bastug et al & 46 & 2082.42 & 2120.33 & 145 & 766.47 & 864.89 & & 1.02 & {$[0.68: 1.37]$} & $2.8 \%$ \\
\hline Wang et al & 18 & 688.30 & 804.23 & 49 & 222.78 & 102.31 & & 1.09 & {$[0.52 ; 1.67]$} & $2.3 \%$ \\
\hline Liao et al & 231 & 4083.14 & 3771.46 & 149 & 767.68 & 1003.93 & & 1.10 & {$[0.88 ; 1.32]$} & $2.9 \%$ \\
\hline Higuera et al & 27 & 7765.00 & 9109.00 & 139 & 1871.00 & 4146.00 & & 1.12 & {$[0.69: 1.55]$} & $2.6 \%$ \\
\hline $\mathrm{Z}$ Chen et al & 43 & 2352.91 & 3521.47 & 158 & 411.16 & 203.41 & & 1.19 & {$[0.83 ; 1.55]$} & $2.7 \%$ \\
\hline Ding et al & 30 & 1293.74 & 1223.53 & 281 & 540.82 & 396.83 & & 1.41 & {$[1.02,1.80]$} & $2.7 \%$ \\
\hline J Zhao et al & 84 & 1303.46 & 305.00 & 499 & 605.78 & 448.95 & & 1.62 & {$[1.37 ; 1.86]$} & $2.9 \%$ \\
\hline$J$ Zhang et al & 209 & 3764.39 & 2588.56 & 252 & 747.36 & 574.03 & & 1.68 & {$[1.47 ; 1.89]$} & $3.0 \%$ \\
\hline P Wang et al & 18 & 3073.13 & 3630.59 & 101 & 659.58 & 378,12 & & 1.68 & {$[1.13: 2.23]$} & $2.4 \%$ \\
\hline Yue et al & 20 & 1435.32 & 1179.11 & 160 & 467.27 & 433.40 & & 1.71 & {$[1.22 ; 2.21]$} & $2.5 \%$ \\
\hline Aloisio et al & 47 & 21194.06 & 24598.98 & 322 & 3337.35 & 5901.13 & & 1.73 & {$[1.40 ; 2.06]$} & $2.8 \%$ \\
\hline Randc & 17238 & & & 9720 & & & & 0.70 & $0.88]$ & $100.0 \%$ \\
\hline \multirow{2}{*}{\multicolumn{5}{|c|}{ Heterogeneity: $I^{2}=94 \%, \tau^{2}=0.2636[0.1616 ; 0.4738] . \rho<0.01$}} & & & & & & \\
\hline & & & & & & & -1 & 2 & & \\
\hline
\end{tabular}

234 Figure 3. Forest plot of association between COVID-19 severity and platelets (A), D-dimers (B). 
medRxiv preprint doi: https://doi.org/10.1101/2021.10.17.21265108; this version posted October 18, 2021. The copyright holder for this preprint (which was not certified by peer review) is the author/funder, who has granted medRxiv a license to display the preprint in perpetuity. It is made available under a CC-BY-NC-ND 4.0 International license .

\section{A Fibrinogen}
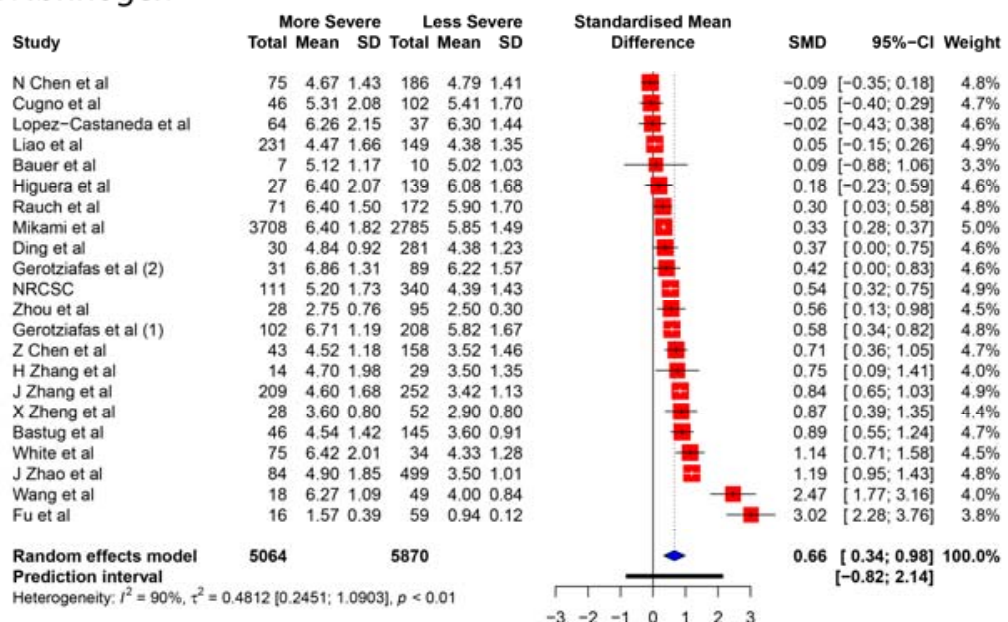

B Activated partial thromboplastin time

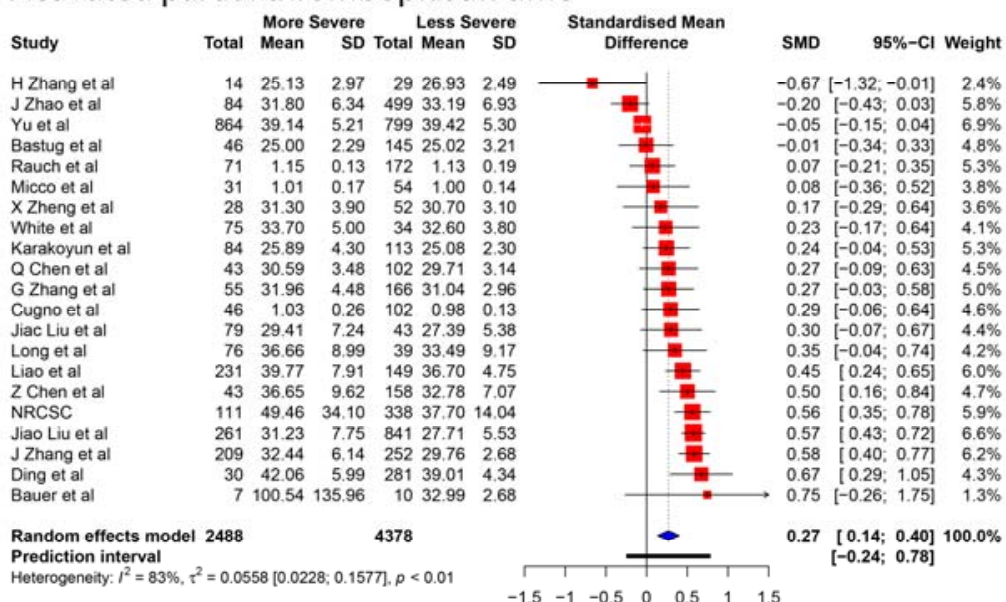

\section{Prothrombin time}

\begin{tabular}{|c|c|c|c|c|c|c|}
\hline \multirow[b]{2}{*}{ Study } & \multicolumn{3}{|c|}{ More Severe } & \multicolumn{3}{|c|}{ Less Seve } \\
\hline & Total & Mean & SD & Total & Mean & \\
\hline Zhou et al & 28 & 15.80 & 1.20 & 95 & 16.20 & 0.60 \\
\hline Cugno et al & 46 & 1.15 & 0.11 & 102 & 1.25 & 0.40 \\
\hline J Zhao et al & 84 & 12.25 & 1.28 & 499 & 12.51 & 1.04 \\
\hline Gerotziafas et al (2) & 31 & 14.80 & 1.99 & 89 & 14.61 & 1.65 \\
\hline Rauch et al & 71 & 1.11 & 0.10 & 172 & 1.10 & 0.09 \\
\hline Ding et al & 30 & 13.50 & 0.86 & 281 & 13.40 & 0.59 \\
\hline Q Chen et al & 43 & 11.98 & 0.80 & 102 & 11.85 & 0.82 \\
\hline Long et al & 76 & 12.71 & 2.35 & 39 & 12.34 & 1.91 \\
\hline $\mathrm{J}$ Zhang et al & 209 & 13.58 & 2.26 & 252 & 13.28 & 1.09 \\
\hline Yu et al & 864 & 13.95 & 0.97 & 799 & 13.75 & 0.83 \\
\hline White et al & 75 & 13.87 & 1.69 & 34 & 13.51 & 1.47 \\
\hline Jiac Liu et al & 79 & 11.44 & 1.48 & 43 & 11.13 & 1.14 \\
\hline NRCSC & 109 & 14.69 & 11.52 & 335 & 12.88 & 5.95 \\
\hline Karakoyun et al & 84 & 12.89 & 1.34 & 113 & 12.56 & 1.27 \\
\hline $\mathrm{Z}$ Chen et al & 43 & 13.62 & 2.85 & 158 & 12.76 & 2.44 \\
\hline Y Zhoo et al & 74 & 12.34 & 0.98 & 211 & 12.04 & 0.82 \\
\hline $\mathrm{H}$ Zhang et al & 14 & 10.63 & 0.57 & 29 & 10.41 & 0.46 \\
\hline $\mathrm{X}$ Zheng et al & 28 & 12.50 & 1.20 & 52 & 12.00 & 1.00 \\
\hline Gerotziafas et al (1) & 102 & 14.75 & 1.27 & 208 & 14.09 & 1.12 \\
\hline Jiao Liu et al & 261 & 12.25 & 1.71 & 841 & 11.41 & 1.21 \\
\hline Jie Liu et al & 152 & 12.67 & 1.25 & 62 & 11.90 & 1.20 \\
\hline$G$ Zhang et al & 55 & 13.62 & 1.91 & 166 & 12.78 & 0.97 \\
\hline Liao et al & 231 & 15.46 & 4.50 & 149 & 13.10 & 0.90 \\
\hline Bastug et al & 46 & 13.49 & 1.38 & 145 & 12.46 & 0.98 \\
\hline $\begin{array}{l}\text { Random effects model } \\
\text { Prediction interval }\end{array}$ & & & & & & \\
\hline
\end{tabular}

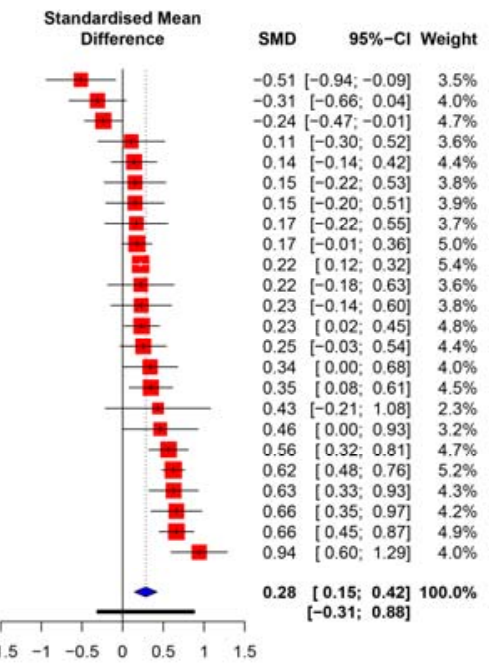

Figure 4. Forest plots of the association between COVID-19 severity and: (A) fibrinogen,

238 (B) activated partial thromboplastin time, (C) prothrombin time. 
medRxiv preprint doi: https://doi.org/10.1101/2021.10.17.21265108; this version posted October 18, 2021. The copyright holder for this preprint (which was not certified by peer review) is the author/funder, who has granted medRxiv a license to display the preprint in perpetuity.

It is made available under a CC-BY-NC-ND 4.0 International license .

Table 1. Summary of the effect sizes for all coagulation parameters

\begin{tabular}{llllllll} 
& \multicolumn{3}{c}{ Effect Size } \\
\cline { 2 - 8 } Parameter & $\begin{array}{l}\text { Pooled } \\
\text { SMD }\end{array}$ & $95 \%$ CI & $\mathrm{t}$ & $\mathrm{p}$ value & $\mathrm{I}^{\wedge} 2(\%)$ & tau-squared & $\mathrm{p}$ value \\
\hline PLT & -0.1684 & {$[-0.2826 ;-0.0542]$} & -3 & 0.0051 & 82.2 & 0.0743 & $<0.0001$ \\
DD & 0.6985 & {$[0.5155 ; 0.8815]$} & 7.74 & $<0.0001$ & 94.2 & 0.2636 & $<0.0001$ \\
FIB & 0.661 & {$[0.3387 ; 0.9833]$} & 4.27 & 0.0003 & 90.4 & 0.4812 & $<0.0001$ \\
APTT & 0.2683 & {$[0.1357 ; 0.4009]$} & 4.22 & 0.0004 & 82.8 & 0.0558 & $<0.0001$ \\
PT & 0.284 & {$[0.1472 ; 0.4208]$} & 4.3 & 0.0003 & 80 & 0.0785 & $<0.0001$
\end{tabular}

\subsubsection{Sensitivity and Subgroup Analysis}

242 Neither the analysis by the leave-one-out method nor the influence diagnostic has identified

243 studies that solely cause a significant change in the effect size estimates. Removal of several

244 outliers based on the pooled and individual confidence intervals allowed significant decrease

245 in heterogeneity, yet it did not affect the interpretation of the results. Adjusted effect sizes

246 and heterogeneity measurements are summarized in Table 2. All influence diagnostic plots,

247 such as Baujat and leave-one-out plots, Cook's distance, Covariance Ratio, etc., are provided

248 in the Suppl. Figures 1-16 along with resulting Forest plots.

249 GOSH plots were built for all five models. K-means, DBSCAN, and Gaussian Mixture

250 Model were implemented as clustering methods. This diagnostic was not applied on PLT and

251 DD since they only have one cluster each (Figure 5); for FIB, APTT, and PT, on the other

252 hand, we constructed the plots and identified several possible influential cases. Original

253 GOSH plots for these parameters are given at Suppl. Figures. For fibrinogen, models that

254 include studies by Fu et al. (2020) and Wang et al. (2020) tend to show higher heterogeneity

255 and greater effect size (Figure 6A-B). For activated partial thromboplastin time, GOSH plot

256 demonstrated that studies by J. Zhao et al. (2021), H. Zhang et al (2020), and Yu et al. (2020)

257 increase model's heterogeneity and slightly pull the effect size to the left (Figure 6C-E). 
258 GOSH plots of the prothrombin time effect size identified four studies, three of which (J.

259 Zhao et al (2021), Cugno et al. (2021), and Zhou et al. (2021) pull effect size to the left

260 (Figure 6F-H), and one (Bastug et al.) pulls effect size to the right (Figure 6I). We've

261 excluded these studies and recalculated the pooled effect size for each parameter. Results are

262 summarized in Table 2.

263 To explore the possible sources of heterogeneity and test the robustness of our data, we 264 have conducted subgroup analyses based on articles' country of origin and criteria for 265 severity stratification. Results are summarized in Table 3. Subgroup analysis showed no 266 significant difference between articles originated from different countries but revealed that 267 severity assessment criteria might have an influence on overestimated effect sizes for PLT and DD. High heterogeneity levels seem to be persistent oven different subgroups. Being the only exception, values of APTT obtained from non-Chinese articles were less heterogenous -

$27047.1 \%$ compared to $84.7 \%$ in studies originated in China.

A Plàtélétśs

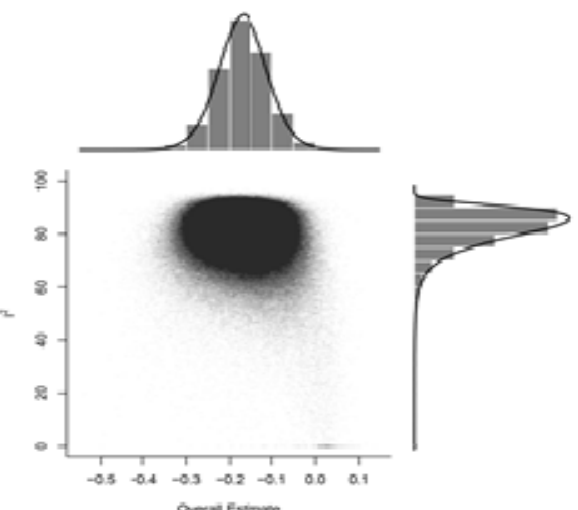

B D-dimers

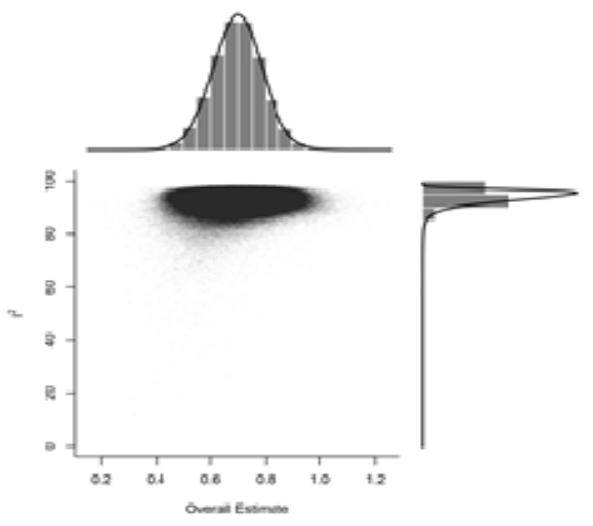

271

272 273

Figure 5. GOSH diagnostic for influential cases in meta-analysis models (A) - PLT, (B) DD. 
medRxiv preprint doi: https://doi.org/10.1101/2021.10.17.21265108; this version posted October 18, 2021. The copyright holder for this preprint (which was not certified by peer review) is the author/funder, who has granted medRxiv a license to display the preprint in perpetuity.

\section{It is made available under a CC-BY-NC-ND 4.0 International license .}

A Fibrinogen (Fu et al)

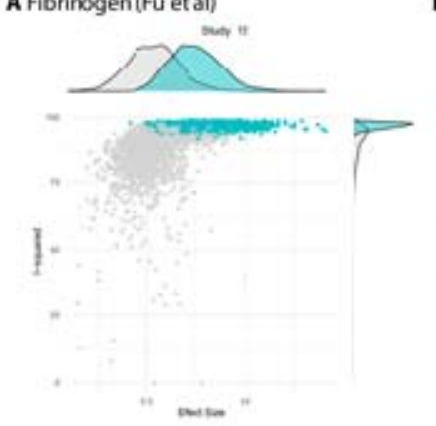

D APTT (H Zhang et al)

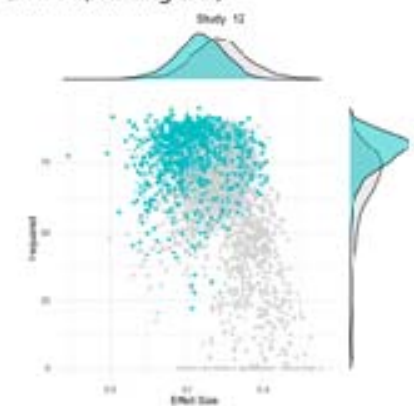

G Prothrombin time (Cugno etal)

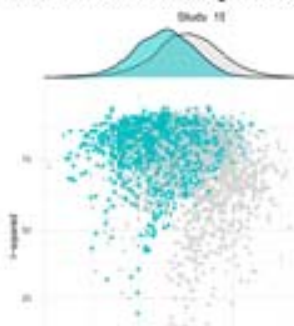

B fbrinogen (Wanget al)

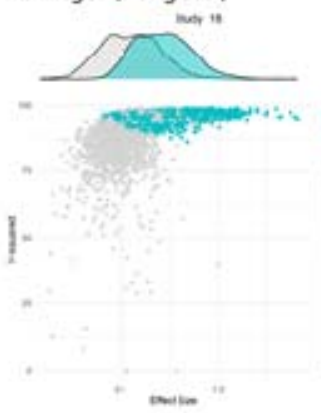

E APTT (ro et al)

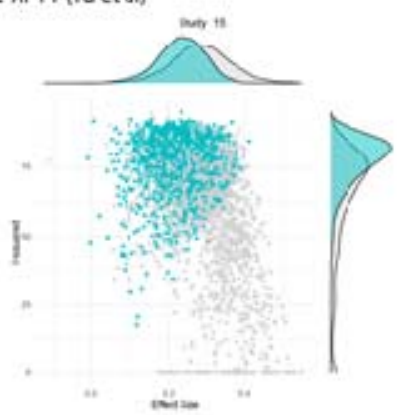

H Prothrombh time (Zhou et all

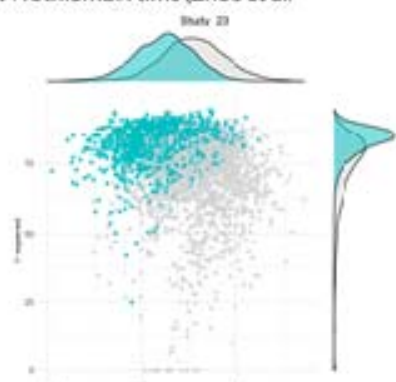

C APTT (. Zhac et al)

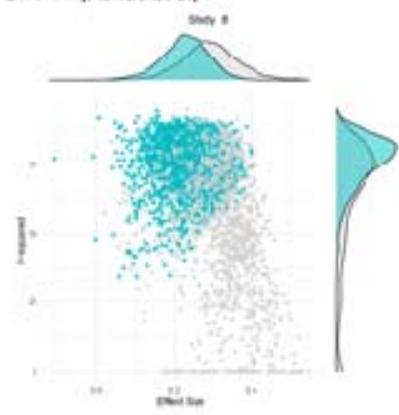

F Prothrombin time (0 Zhao et al)

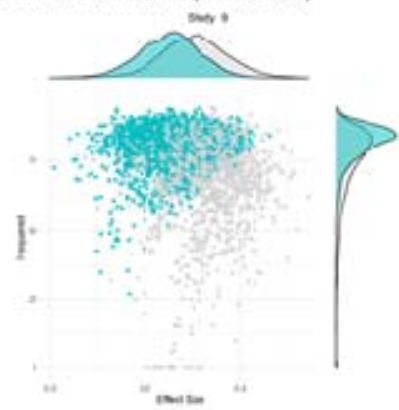

I Frothrombin time 'Bastug et al)

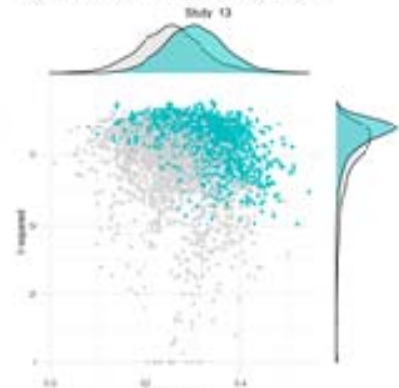

275 Figure 6. GOSH plots fixed for influential studies in meta-analysis models. (A-B) -

276 fibrinogen; (C-E) - APTT; (F-I) - prothrombin time. 
medRxiv preprint doi: https://doi.org/10.1101/2021.10.17.21265108; this version posted October 18, 2021. The copyright holder for this preprint (which was not certified by peer review) is the author/funder, who has granted medRxiv a license to display the preprint in perpetuity.

It is made available under a CC-BY-NC-ND 4.0 International license .

279 Table 2. Summary results of the sensitivity analysis

\begin{tabular}{|c|c|c|c|c|c|c|c|c|}
\hline \multirow{2}{*}{\multicolumn{2}{|c|}{ Coagulation Parameter }} & \multicolumn{4}{|c|}{ Effect Size } & \multicolumn{3}{|c|}{ Heterogeneity } \\
\hline & & \multirow{2}{*}{$\begin{array}{l}\text { Pooled } \\
\text { SMD } \\
-0.1684\end{array}$} & \multirow{2}{*}{$\frac{95 \% \mathrm{CI}}{[-0.2826 ;-0.0542]}$} & \multirow{2}{*}{$\frac{\mathrm{t}}{-3}$} & \multirow{2}{*}{$\frac{\mathrm{p} \text { value }}{0.0051}$} & \multirow{2}{*}{$\frac{\mathrm{I}^{2}(\%)}{82.2}$} & \multirow{2}{*}{$\begin{array}{l}\begin{array}{l}\text { tau- } \\
\text { squared }\end{array} \\
0.0743\end{array}$} & \multirow{2}{*}{$\begin{array}{l}\begin{array}{l}\mathrm{Q} \text { test } \mathrm{p}- \\
\text { value }\end{array} \\
<0.0001\end{array}$} \\
\hline PLT & Original & & & & & & & \\
\hline & Outliers removed & -0.1416 & {$[-0.2419 ;-0.0412]$} & -2.9 & 0.0076 & 56.3 & 0.0287 & 0.0002 \\
\hline & Inf. Stud. removed & - & - & - & - & - & - & - \\
\hline \multirow[t]{3}{*}{ DD } & Original & 0.6985 & {$[0.5155 ; 0.8815]$} & 7.74 & $<0.0001$ & 94.2 & 0.2636 & $<0.0001$ \\
\hline & Outliers removed & 0.621 & {$[0.4860 ; 0.7560]$} & 9.47 & $<0.0001$ & 70.2 & 0.073 & $<0.0001$ \\
\hline & Inf. Stud. removed & - & - & - & - & - & - & - \\
\hline \multirow[t]{3}{*}{ FIB } & Original & 0.661 & {$[0.3387 ; 0.9833]$} & 4.27 & 0.0003 & 90.4 & 0.4812 & $<0.0001$ \\
\hline & Outliers removed & 0.5889 & {$[0.4141 ; 0.7638]$} & 7.14 & $<0.0001$ & 85 & 0.0801 & $<0.0001$ \\
\hline & Inf. Stud. removed & 0.4855 & {$[0.3030 ; 0.6679]$} & 5.57 & $<0.0001$ & 86.1 & 0.1175 & $<0.0001$ \\
\hline \multirow[t]{3}{*}{ APTT } & Original & 0.2683 & [0.1357; 0.4009] & 4.22 & 0.0004 & 82.8 & 0.0558 & $<0.0001$ \\
\hline & Outliers removed & 0.348 & {$[0.2450 ; 0.4518]$} & 7.14 & $<0.0001$ & 38.6 & 0.0125 & 0.0532 \\
\hline & Inf. Stud. removed & 0.3214 & {$[0.2036 ; 0.4392]$} & 5.73 & $<0.0001$ & 68.8 & 0.0326 & $<0.0001$ \\
\hline \multirow[t]{2}{*}{$\mathrm{PT}$} & Original & 0.284 & {$[0.1472 ; 0.4208]$} & 4.3 & 0.0003 & 80 & 0.0785 & $<0.0001$ \\
\hline & Outliers removed & 0.293 & {$[0.2099 ; 0.3761]$} & 7.44 & $<0.0001$ & 26.9 & 0.0064 & 0.1407 \\
\hline
\end{tabular}


283 Table 3. Summary results of the subgroup analysis

$\begin{array}{llllllll}\text { Inf. Stud. removed } & 0.283 & {[0.1336 ; 0.4325]} & 3.94 & 0.0008 & 81 & 0.0877 & <.0001\end{array}$

\begin{tabular}{|c|c|c|c|c|c|c|}
\hline \multirow[b]{2}{*}{$\begin{array}{l}\text { Coag. } \\
\text { Param. }\end{array}$} & \multirow[b]{2}{*}{ Variable } & \multirow[b]{2}{*}{ Subgroups } & \multicolumn{2}{|r|}{ Effect Size } & \multicolumn{2}{|c|}{ Heterogeneity } \\
\hline & & & $\mathrm{k}$ & SMD [95\%CI] & $\mathrm{I}^{2}(\%)$ & $\begin{array}{l}\text { tau- } \\
\text { squared }\end{array}$ \\
\hline \multirow[t]{8}{*}{ PLT } & Location & & & & & \\
\hline & & China & 19 & $-0.2256[-0.3747 ;-0.0764]$ & 84.6 & 0.0694 \\
\hline & & Other & 15 & $-0.1384[-0.3037 ; 0.0270]$ & $73.60 \%$ & 0.0765 \\
\hline & Criteria & & & & & \\
\hline & & Guidelines & 19 & $-0.1618[-0.3319 ; 0.0082]$ & 85.10 & 0.0983 \\
\hline & & $\mathrm{ICU}$ & 9 & $-0.1188[-0.3056 ; 0.0680]$ & 70.60 & 0.0308 \\
\hline & & Aggravation & 3 & $-0.0948[-0.8750 ; 0.6854]$ & 74.60 & 0.0682 \\
\hline & & Oxygen Therapy & 3 & $-0.6834[-1.4303 ; 0.0636]$ & 0.00 & 0 \\
\hline
\end{tabular}

DD Location

$\begin{array}{lllll}\text { China } & 23 & 0.7618[0.5089 ; 1.0148] & 94.70 & 0.3043 \\ \text { Other } & 14 & 0.5992[0.3204 ; 0.8780] & 91.60 & 0.1964\end{array}$

Criteria

$\begin{array}{lllll}\text { Guidelines } & 22 & 0.6349[0.4248 ; 0.8450] & 92.10 & 0.1903 \\ \text { ICU } & 12 & 0.9257[0.5007 ; 1.3506] & 96.70 & 0.4027 \\ \text { Aggravation } & 3 & 0.2526[-0.2458 ; 0.7510] & 54.60 & 0.0182\end{array}$

FIB Location
China
$110.9393[0.3154 ; 1.5632]$
$93.50 \quad 0.8093$
Other
110.4162 [0.1757; 0.6567$]$
$74.50 \quad 0.0937$

Criteria

$$
\begin{array}{lllll}
\text { Guidelines } & 13 & 0.8539[0.3128 ; 1.3949] & 92.60 & 0.7496 \\
\text { ICU } & 8 & 0.4510[0.1690 ; 0.7330] & 84.30 & 0.0814 \\
\text { Aggravation } & 1 & 0.3031[0.0253 ; 0.5809] & - & -
\end{array}
$$

0.0263

0.2123

p-

0.3596

0.0041

0.0813

0.156

APTT Location
China
130.2768 [0.0730; 0.4806]
$88.30 \quad 0.0872$
Other
$8 \quad 0.2499$ [0.0661; 0.4337]
$\begin{array}{ll}47.10 & 0.0169\end{array}$

0.8248

Criteria
Guidelines
$160.2629[0.1019 ; 0.4240]$
$84.70 \quad 0.0636$
ICU
$40.3500[-0.1307 ; 0.8306]$
$70.60 \quad 0.052$
Aggravation
$1 \quad 0.0714[-0.2051 ; 0.3480]$

0.359 
PT Location

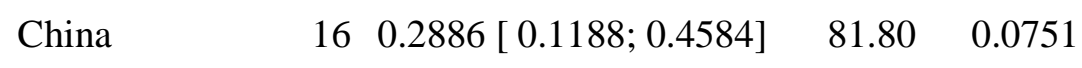

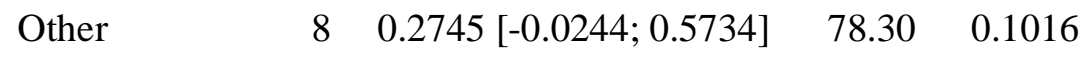

Criteria

\begin{tabular}{lllll} 
Guidelines & 18 & $0.2889[0.1401 ; 0.4377]$ & 79.00 & 0.0628 \\
ICU & 5 & $0.2992[-0.2853 ; 0.8836]$ & 87.6 & 0.1962 \\
Aggravation & 1 & $0.1407[-0.1360 ; 0.4175]$ & - & - \\
\hline
\end{tabular}

\subsubsection{Publication Bias}

286 Contour-enhanced funnel plots for five coagulation parameters are depicted in Figure 7, and the results of Egger's test are summarized in Table 4. Based on the linear regression results, significant asymmetry is observed in published studies that included results for PLT, DD (Intercept [p-value]: -1.297 [0.0336], 3.182 [0.0013]), and somewhat significant asymmetry was indicated for FIB (1.872 [0.0493]). While it is impossible to predict whether asymmetry is coming solely from publication bias, contour-enhanced funnel plots for DD and FIB (Figure 6B-C) show that the number of papers with insignificant findings is very small $(\mathrm{p}>0.1)$. This may advocate for the presence of some publication bias. In contrast, Figure 6A illustrates that even though the funnel plot for PLT has some asymmetry, there are plenty of publications with insignificant SMDs, thus decreasing the possibility of publication bias.

296 To further explore the robustness of our findings, we have conducted several additional tests. As reported by Zwetsloot (2017) and his colleagues, plotting SMD against its standard error to assess the publication bias can result in distorted funnel plots, leading to falsepositive conclusions. Since SMD is necessary for our analysis and cannot be substituted, we used a sample size-based precision estimate instead of the standard error $-1 / \sqrt{ } \mathrm{n}$. The resulting funnel plots (Supplemental Figure 16) showed no significant distortion.

302 Similar corrections were made to Egger's test: since standardized mean difference and 303 standard error are not independent, we can expect the test to yield some false-positive results. 
304 In our calculations, we used the corrected SE suggested by Pustejovsky and Rodgers (2019).

305 Results are given in the Supplemental Table 2. The only model that was affected by this 306 correction was FIB (intercept 2.142 with a p-value of 0.0526 compared to the initial 1.872 307 and 0.0493), indicating that previously concluded asymmetry might have been a false 308 positive. Interpretation of results for other parameters remained the same.
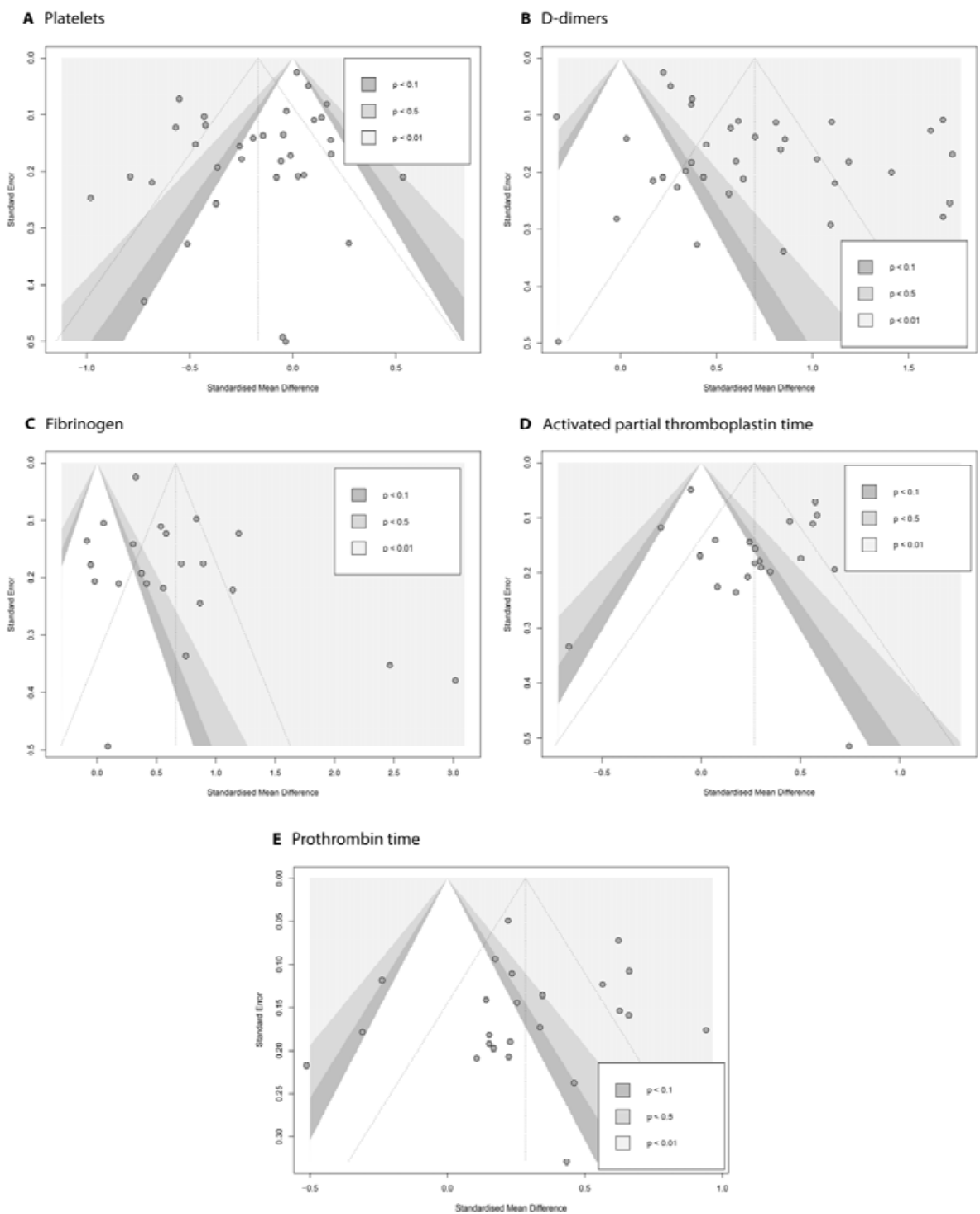

310 Figure 7. Contour-enhanced funnel plots evaluating the presence of publication bias in the pool of articles that report association between COVID-19 severity and (A) platelets; (B) Ddimer; (C) fibrinogen; (D) activated partial thromboplastin time; (E) prothrombin time. 
313 Table 4. Egger's test for publication bias

\begin{tabular}{lllll}
\hline Parameter & Intercept & Confidence Interval & $\mathrm{t}$ & $\mathrm{p}$-value \\
\hline PLT & -1.297 & {$[-2.44,-0.15]$} & -2.221 & 0.0336 \\
DD & 3.182 & {$[1.39,4.97]$} & 3.489 & 0.0013 \\
FIB & 1.872 & {$[0.12,3.63]$} & 2.093 & 0.0493 \\
APTT & 0.775 & {$[-1.37,2.92]$} & 0.708 & 0.4874 \\
PT & -0.436 & {$[-2.49,1.62]$} & -0.417 & 0.6811 \\
\hline
\end{tabular}

\section{Discussion}

There is a need to identify early indicators of the risk of critical patients progressing to

317 ICU at COVID-19. Abnormal coagulation parameters, including DD and FIB levels, changes in PLT, and PT, are observed in many patients with COVID-19 infection at admission (rev.

319 Levi et al., 2020; Iba et al., 2020). However, as discussed by different authors, these indicators provide contradictory information regarding risk stratification and prognosis (Luo et al., 2020; Tang et al., 2020; Ding et al., 2021). There are several previous meta-analysis reviews researching abnormal coagulation and the severity of COVID-2019 infection. The

323 majority of analyzed studies were conducted at the beginning of the pandemic and examined 324 the Chinese population of patients (before April 2020 - Xiong et al., 2020; Lippi et al., 2020; 325 Zhang et al., 2020; Zhu et al., 2021; June 2020 -Di Minno et al., 2020). Through our meta326 analysis study, it was revealed that DD and FIB levels, APTC, and prothrombin time were 327 significantly higher in the severe group of COVID-19 patients. In contrast, PLT was 328 significantly lower in these patients. There was no evidence of effects across different 329 geographic subgroups, with the exception of APTT values. 
medRxiv preprint doi: https://doi.org/10.1101/2021.10.17.21265108; this version posted October 18, 2021. The copyright holder for this preprint (which was not certified by peer review) is the author/funder, who has granted medRxiv a license to display the preprint in perpetuity.

It is made available under a CC-BY-NC-ND 4.0 International license.

\subsection{Platelet changes}

In this meta-analysis, we systematically analyze evidence for the utility of lowered PLT levels on admission in the relationship to the severity of infection. Platelets play a crucial role in the maintenance of hemostasis, contribute to thromboinflammatory processes (van der Meijden, Heemskerk, 2019) and at different stages of viral infection, changes in platelet production or destruction may result in coagulation imbalances leading to pro-thrombotic events or in platelet disfunction and bleeding risks (Assinger, 2014), and increased activation of platelets (Hottz et al., 2020; Zaid et al., 2020; Althaus et al., 2021). Thrombocytopenia (platelet count $<150 \times 10^{9} / \mathrm{L}$ ) seems to represent an important marker of COVID-19 severity (Qu et al., 2020; Yang et al., 2020; Lippi et al., 2020; Iba et al., 2020) and mortality outcome (Lippi et al., 2020; Yang et al., 2020). The reasons for a thrombocytopenia are multi-factorial, which may include early suppression of megakaryocytes production and damage in bone marrow and lungs, hemophagocytosis, immune destruction of platelets and other reasons. Significant thrombocytopenia in COVID-19 is less frequent than it was reported for the largest SARS-1 cohort (45\%) (Lee et al., 2003). SARS-1 induced platelet depletion was related to direct infection of megakaryocytes and hematopoietic progenitors (rev. by Yang et al., 2005). However, almost half of patients presented thrombocytosis following initial thrombocytopenia during SARS epidemics in 2003 (Wong et al., 2003). Recently, a different trend in platelet changes in COVID-19 patients with immune thrombocytic purpura (ITP) was reported by Cruz-Benito et al. (2021). Secondary to SARS-CoV2 infection in ITP-patients generally develops early thrombocytosis (Cruz-Benito et al., 2020). Only a few cases of thrombocytosis (in children) were reported during SARS-CoV2 pandemics (Feld et al., 2020) as part of a multisystem inflammatory syndrome in children associated with COVID-19 (MIS-C) (Yasuhara et al., 2020). It is possible that opposite PLT changes may reflect different phases of COVID-19 infection (Thachil et al., 2020) - acute and convalescent 
medRxiv preprint doi: https://doi.org/10.1101/2021.10.17.21265108; this version posted October 18, 2021. The copyright holder for this preprint (which was not certified by peer review) is the author/funder, who has granted medRxiv a license to display the preprint in perpetuity.

It is made available under a CC-BY-NC-ND 4.0 International license .

phases, though the explanation has not been established yet. The reactive thrombocytosis that

may occur during the convalescent phase requires time observation that would include a period preceding patient discharge. The increase of immature reticulated platelets reported recently in COVID-19 patients by different groups (Cohen et al., 2021; Welder et al., 2021) may play a role in the limiting of effectiveness of anti-platelet therapies (Guthikonda et al., 2007; Ibrahim et al., 2012; Armstrong et al., 2017). Change in platelets parameters (increased mean volume) (Lippi et al., 2021) and reactivity are suggested to be associated with a severe COVID-19 infection (Hottz et al., 2020; Yatim et al., 2021).

\subsection{DD and FIB levels, and Thromboembolic complications}

Concordant with other studies, we found DD and FIB levels significantly elevated in severe COVID-19 infection, though DD levels results may suffer from some publication bias as revealed by meta-regression analysis. It may be related to the variability of DD assays used in the different studies: they are not directly comparable due to the difference in the monoclonal antibodies used for tests (Olson et al., 2013; rev. Goodwin et al., 2017). As confirmed by autopsy results, the elevated DD levels can be associated with fibrin deposits within pulmonary extravascular space and alveoli (Fox et al., 2020), but they may be nonspecific to intravascular fibrin formation (Hunt et al., 2020). High DD levels, together with elevated neutrophils, were reported to be predictive factors of pulmonary embolism in COVID-19 patients (Thoreu et al., 2021). Thromboembolic complications related to COVID19 are responsible for a substantial mortality rate (Lodigiani et al., 2020; Kunutsor, Laukannen, 2020; Piazza et al., 2020; Grillet et al., 2020). Whereas the highest burden of thromboembolism is associated with patients in the ICU (Helms et al., 2020; Llitjos et al., 2020; Klok et al., 2020), patients in non-ICU settings also bear a significant risk of these complications, especially VTE (venous thromboembolism) (Lodigiani et al., 2020; Spyropoulos et al., 2020), as well as pulmonary embolism (Thoreau et al., 2021). Klock and 
medRxiv preprint doi: https://doi.org/10.1101/2021.10.17.21265108; this version posted October 18, 2021. The copyright holder for this preprint (which was not certified by peer review) is the author/funder, who has granted medRxiv a license to display the preprint in perpetuity.

It is made available under a CC-BY-NC-ND 4.0 International license.

381 colleagues (2020) report that in spite of thrombosis prophylaxis, a high incidence of 382 thrombotic complications in ICU patients is comparable with patients from other groups with

383 DIC (disseminated intravascular coagulation). Moreover, multiple studies describe cerebral 384 venous thrombosis (CVT) associated with COVID-19 infection (Garaci et al., 2020; Baudar 385 et al., 2020). DD and FIB levels are elevated in COVID-19 and in thromboembolism, and 386 therefore as single tests are unspecific and unhelpful in the differentiation of these conditions. 387 In part, it may be explained by the involvement in abnormal coagulation at COVID-19 of 388 resulting in changes undetected by routine tests (Holter et al., 2020; Cugno et al., 2021). The dysfunction of endothelial cells with COVID-19 may contribute to excess thrombin generation and fibrinolysis shutdown, which is associated with VTE, stroke and, renal failure (Wright et al., 2020). There are different suggestions for COVID-19 risk stratification related to changes in platelets and endothelial cells, such as increased proportion of immature reticulated platelet fraction (Cohen et al., 2021; Welder et al., 2021) or CECs (circulating endothelial cells) counts in the blood representing stressed cells detached from injured vessels, reported in various inflammatory and infective diseases, and are indicative of disease severity (Blann et al., 2006). They were significantly higher in COVID-19 patients admitted to the ICU and positively correlated with the length of hospital stay (Guervilly et al., 2020). This marker is related to SARS-CoV2 directly infecting primary endothelial cells (Monteil et al., 2020). Furthermore, there is some evidence of infection in endothelial cells in severe cases of COVID-19 (Varga et al., 2020), including the presence of coronavirus particles in the cytoplasm of endothelial cells on electron microscopy (Colmenero et al., 2020). Platelets activation and endothelial cell damage in COVID-19 patients are also resulting in elevated 404 levels of extracellular vesicles (EVs) (Capellano et al., 2021) recently associated with 405 severity of disease (Krishnamachary et al., 2021). 
medRxiv preprint doi: https://doi.org/10.1101/2021.10.17.21265108; this version posted October 18, 2021. The copyright holder for this preprint (which was not certified by peer review) is the author/funder, who has granted medRxiv a license to display the preprint in perpetuity.

It is made available under a CC-BY-NC-ND 4.0 International license .

\subsection{Fibrinolysis shutdown requires evaluation outside conventional coagulation} parameters

Fibrinolysis shutdown is induced by severe COVID-19 infection (Tang et al., 2020; Wright et al., 2020; Collett et al., 2021) and is partly responsible for high DD and FIB levels. Some pathophysiological changes may contribute to high procoagulant conditions secondary to COVID-19 infection. Thus, low plasminogen levels (Correa et al., 2020), similar to plasminogen-related fibrinolysis observed at other viral infections such as influenza infection (Berri et al., 2013), may lead to a hypercoagulability state. A multiplexed analysis of inflammation-related gene expression (249 genes from nCounter Inflammation panel; NanoString Technologies, USA) revealed similarities between lung specimens in influenza and Covid-19 groups (Ackermann et al., 2020). Depression of fibrinolysis was reported not only in ICU patients with severe infection and clinical signs of thromboembolism (Wright et al., 2020), but also in the general unselected ICU cohort (Correa et al., 2020; Collett et al., 2020; Nougier et al., 2020). Viscoelastic testing (ROTEM, tissue-type plasminogen activator (tPA) ROTEM, TEG) and evaluation of clot formation by Clot Waveworm analysis have demonstrated a hypercoagulable state, characterized by increased clot stiffness and severely impaired fibrinolysis (Nougier et al., 2020; Collett et al., 2020; Panigada et al., 2020; Pavoni et al., 2020; Fan et al., 2021; Hulshof et al., 2021). Elevated routine coagulation parameters taken at admission may help with initial differentiation of severe and non-severe COVID-19 patient groups, but they do not provide information about fibrinolysis shutdown.

Although our findings were consistent across different geographic groups, they were tempered by significant heterogeneity. The DD, FIB, and PLT elevation trends speak about the necessity of investigating the potential of additional specific biomarkers for stratification of COVID-19 patients at risk for fibrinolytic shutdown and associated micro-and macrovascular events. We suggest that thorough characterization of platelets including a proportion 
medRxiv preprint doi: https://doi.org/10.1101/2021.10.17.21265108; this version posted October 18, 2021. The copyright holder for this preprint (which was not certified by peer review) is the author/funder, who has granted medRxiv a license to display the preprint in perpetuity.

It is made available under a CC-BY-NC-ND 4.0 International license .

431 of immature reticulated platelets and their size/mean volume parameters as well as a clot

432 formation testing requires to evaluate a risk of thromboembolic events in COVID-19 patients

433 groups.

\section{Limitations of the study}

435 Our findings should be interpreted with some limitations. Firstly, most of the included 436 studies were either retrospective and observational by design, thus prone to recall or 437 misclassification bias. Second, such studies often imply recruitment by convenience 438 sampling, in which case the representativeness of a study is questioned. The random effects 439 model was used due to the high heterogeneity of research. In the context of this metaanalysis, several different endpoints were allowed: severity guidelines, ICU admissions, oxygen therapy requirement, and disease aggravation. In an attempt to overcome this issue,

442 we have conducted a subgroup analysis. Third, uncontrolled variables might also pose a

443 limitation - both the disease severity and coagulation parameters can be affected by several 444 potential confounding variables, such as comorbidities, age, etc. Some studies have reported 445 their results in terms of quartiles or maximum and minimum values. The necessity to convert 446 values could potentially influence the results. Although sensitivity and subgroup analyses 447 were conducted, some residual heterogeneity may affect the interpretation of results. Finally, 448 the underlying mechanisms of coagulation markers at COVID-19 still need to be 449 investigated.

\section{Conclusions}

451 Our findings support using a combination of coagulation parameters for risk stratification 452 of patients with COVID-19 infection at the time of admission. However, additional 453 evaluation using clotting formation methods or combination with platelet-specific biomarkers 454 requires. This information may help physicians triage patients with thromboembolism. An 
455 important consideration is an intermediate and long follow-up of COVID-19 patients. We

456 hypothesize that increase in platelets turnover towards immature reticulated forms contribute

457 to hypercoagulability state at COVID-19 patients and their resistance to anti-platelet therapy.

458 Future research should take in account change in platelet parameters and platelet

459 fragmentation leading to elevated levels of extracellular vesicles.

4607 Data availability Statement

461 Data are available by request from co-corresponding authors.

\section{Conflict of Interest}

463 The authors declare no conflict of interest.

\section{Author Contributions}

465 P.L. - conceptualization, methodology, formal analysis, investigation, data curation, writing 466 original draft, G.I., Z.S., A.K. - methodology, data curation, formal analysis, investigation; 467 A.T.T., M.M.S., A.S.D., M.M.A., M.S.B. - methodology, formal analysis, investigation, data 468 curation of NRCSC cohort, writing a draft; E.D.P., A.T.- methodology; analysis; funding, 469 N.S.B. - conceptualisation, methodology, formal analysis, investigation, data curation, 470 writing a draft. M.S.B. and N.S.B.- supervision. All authors read and edit a final draft.

\section{$471 \quad 10$ Acknowledgments}

472 We are very grateful to Sadyk Khamitov and Aliya Sailybayeva from the Research

473 Department of National Research Center for Cardiac Surgery for their excellent 474 organizational help. N.S.B. and A.T. were supported by FDCRGP SSH2020028, and N.S.B. 475 by OPCRP2020018 grants from Nazarbayev University. 


\section{Abbreviations}

477 APTT - activated partial thromboplastin time; CI - confidence interval; DD - D-dimer; DIC 478 disseminated intravascular coagulation; FIB - fibrinogen; GOSH - graphical display of study 479 heterogeneity; ICU - intensive care unit; MERS-CoV - Middle East respiratory syndrome coronavirus (MERS-CoV); NRCSC - National Research Center for Cardiac Surgery; PLT -

481 platelets; PT - prothrombin time; ROTEM - rotation thromboelastometry; SARS-CoV -

482 severe respiratory acute syndrome coronavirus (SARS-CoV); SMD - standardized mean 483 difference; tPA - tissue-type plasminogen activator; VTE - venous thromboembolism; vWF 484 - von Willebrand factor.

\section{References}

487 Ackermann, M., Verleden, S.E., Kuehnel, M., Haverich, A., Welte, T., Laenger, F., et al. 488 (2020). Pulmonary vascular endothelialitis, thrombosis, and angiogenesis in Covid-19. N. 489 Engl. J. Med. 383, 120-128. doi: 10.1056/NEJMoa2015432

490 Aloisio, E., Chibireva, M., Serafini, L., Pasqualetti, S.S.F., Dolci, A., Panteghini, M., et al. 491 (2020). A comprehensive appraisal of laboratory biochemistry tests as major predictors of 492 COVID-19 severity. Arch. Pathol. Lab. Med. 144, 1457-1464. doi: 10.5858/arpa.2020-0389sa

494 Althaus, K., Marini, I., Zlamal, J., Pelzl, L., Singh, A., Häberle, H., et al. (2021). Antibody495 induced procoagulant platelets in severe COVID-19 infection. Blood. 137, 1061-1071. doi: 496 10.1182/blood.2020008762

497 Armstrong, P.C., Hoefer, T., Knowles, R.B., Tucker, A.T., Hayman, M.A. et al. (2017) 498 Newly formed reticulated platelets undertmine pharmacokinetically short-lived antiplatelet 
medRxiv preprint doi: https://doi.org/10.1101/2021.10.17.21265108; this version posted October 18, 2021. The copyright holder for this preprint (which was not certified by peer review) is the author/funder, who has granted medRxiv a license to display the preprint in perpetuity.

It is made available under a CC-BY-NC-ND 4.0 International license .

499 therapies. Atherosclerosis, Thromb. Vascular Biol. 37, 949-956. 500 doi.org/10.1161/ATVBAHA.116.308763

501 Assinger, A. (2014). Platelets and infection-an emerging role of platelets in viral infection. 502 Front. Immunol. 5, 649. doi: 10.3389/fimmu.2014.00649

503 Bastug, A., Bodur, H., Erdogan, S., Gokcinar, D., Kazancioglu, S., Deniz, B., et al. (2020). 504 Clinical and laboratory features of COVID-19: predictors of severe prognosis. Int. 505 Immunopharmacol. 88:106950. doi: 10.1016/j.intimp.2020.106950

506 Baudar, C., Duprez, T., Kassab, A., Miller, N., Rutgers, M.P. (2020). COVID-19 as 507 triggering co-factor for cortical cerebral venous thrombosis? J Neuroradiol. 2020, 30205508 302144. doi: 10.1016/j.neurad.2020.06.008

509 Bauer, W., Galtung, N., Neuwinger, N., Kaufner, L., Langer, E., Somasundaram, R., et al. 510 (2021). A matter of caution: coagulation parameters in COVID-19 do not differ from patients 511 with ruled-out SARS-CoV-2 infection in the emergency department. TH Open. 5, e43-e55. 512 doi: $10.1055 / \mathrm{s}-0040-1722612$

513 Becker, R.C., Sexton, C., Smyth, S. (2021). COVID-19 and biomarkers of thrombosis: focus 514 on von Willebrand factor and extracellular vesicles. J. Thromb. Thrombolysis. 1-10. doi: $515 \quad 10.1007 / \mathrm{s} 11239-021-02544-\mathrm{X}$

516 Bergantini, L., Bargagli, E., d'Alessandro, M., Refini, R., Cameli, P., Galasso, L., et al. 517 (2021). Prognostic bioindicators in severe COVID-19 patients. Cytokine. 141, 155455. doi: $518 \quad 10.1016 /$ j.cyto.2021.155455

519 Berri, F., Rimmelzwaan, G.F., Hanss, M., Albina, E., Foucault-Grunenwald, M.L., Le, V.B., 520 et al. (2013). Plasminogen controls inflammation and pathogenesis of influenza virus 521 infections via fibrinolysis. PLoS Pathog. 9, e1003229. doi: 10.1371/journal.ppat.1003229 
medRxiv preprint doi: https://doi.org/10.1101/2021.10.17.21265108; this version posted October 18, 2021. The copyright holder for this preprint (which was not certified by peer review) is the author/funder, who has granted medRxiv a license to display the preprint in perpetuity.

It is made available under a CC-BY-NC-ND 4.0 International license .

522 Blann, A.D., Woywodt, A., Bertolini, F., Bull, T. M., Buyon, J. P., Clancy, R. M., et al.

523 (2005). Circulating endothelial cells. Thromb. Haemost. 93, 228-235. doi: 10.1160/TH04-09-

$524 \quad 0578$

525 Cappellano, G., Raineri, D., Rolla, R., Giordano, M., Puricelli. C., Vilardo, B., et al. (2021)

526 Circulating platelet-derived extracellular vesicles are a hallmark of SARS-Cov-2 infection.

527 Cells 10, 85. 10.3390/cells10010085

528 Cen, Y., Chen, X., Shen, Y., Zhang, X., Lei, Y., Xu, C., et al. (2020). Risk factors for disease 529 progression in patients with mild to moderate coronavirus disease 2019 - a multi-centre 530 observational study. Clin. Microbiol. Infect. 26, 1242-1247. doi: 10.1016/j.cmi.2020.05.04

531 Chen, N., Zhou, M., Dong, X., Qu, J., Gong, F., Han, Y., et al. (2020). Epidemiological and 532 clinical characteristics of 99 cases of 2019 novel coronavirus pneumonia in Wuhan, China: a 533 descriptive study. Lancet. 395, 507-513. doi: 10.1016/S0140-6736(20)30211-7

534 Chen, N., Li, Y., Fan, H., Tian, A., Yuan, H., Jiang, Z., et al. (2020). Analysis of dynamic 535 disturbance in blood coagulation function of patients with coronavirus disease 2019: a 536 retrospective observational study. Medicine. 99, e22635. doi: 510 537 10.1097/MD.0000000000022635

538 Chen, Q., Zheng, Z., Zhang, C., Zhang, X., Wu, H., Wang, J., et al. (2020). Clinical 539 characteristics of 145 patients with coronavirus disease 2019 (COVID-19) in Taizhou, 540 Zhejiang, China. Infection. 48, 543-551. doi: 10.1007/s15010-020-01432-5

541 Chen, Z., Zhang, F., Hu, W., Chen, Q., Li, C., Wu, L., et al. (2021). Laboratory markers 542 associated with COVID-19 progression in patients with or without comorbidity: A 543 retrospective Study. J. Clin. Lab. Anal. 35, e23644. doi: 10.1002/jcla.23644 
medRxiv preprint doi: https://doi.org/10.1101/2021.10.17.21265108; this version posted October 18, 2021. The copyright holder for this preprint (which was not certified by peer review) is the author/funder, who has granted medRxiv a license to display the preprint in perpetuity.

It is made available under a CC-BY-NC-ND 4.0 International license .

544 Cohen, A., Harari, E., Cipok, M., Laish-Farkash, A., Bryk, G., Yahud, E. et al. (2021).

545 Immature platelets in patients hospitalized with COVID-19. J. Thromb. Thrombolysis 51,

546 608-616. doi.org/10.1007/s11239-020-02290-6

547 Collett, L.W., Gluck, S., Strickland, R.M., Reddi, B.J. (2021). Evaluation of coagulation

548 status using viscoelastic testing in intensive care patients with coronavirus disease 2019

549 (Covid-2019): an observational point prevalence cohort study. Austr. Crit. Care. 34, 155-159.

550 doi: 10.1016/j.aucc.2020.07.003

551 Colmenero, I., Santonja, C., Alonso-Riano, M., Hernandez-Martin, A., Andina, D., Wiesner,

552 T., et al. (2020). SARS-CoV2 endothelial infection causes COVID-19 chilblains:

553 histopathological, immunohistochemical and ultrastructural study of seven paediatric cases.

$554 \quad$ Br. J. Dermatol. 183, 729-737. doi: 10.1111/bjd.19327

555 Correa, T.D., Cordioli, R.L., Guerra, J.C.C., da Silva, B.C., Rodrigues, R.R., de Souza, G.M., 556 et al. (2020). Coagulation profile of COVID-19 patients admitted to the ICU: exploratory 557 study. PLoS ONE. 15, e0243604. doi: 10.1371/journal.pone.0243604

558 Creel-Bulos, C., Auld, S.C., Caridi-Scheible, M., Barker, N.A., Friend, S., Gaddh, M., et al. 559 (2021). Fibrinolysis shutdown and a thrombosis in a COVID-19 ICU. Shock. 55, 316-320. 560 doi: 530 10.1097/SHK.000000000000163

561 Cruz-Benito, B., Rivas-Pollmar, M.I., Roman, M.T.A., Trelles-Martinez, R., Martin-Salces, 562532 M., Lazaro-del Campo, P. et al. (2020). Paradoxical effect of SARS-CoV2 infection with 563 immune thrombocytopenia. Br. J. Haematol. 192, 973-977. doi: 10.1111/bjh.17077

564 Cugno, M., Meroni, P. L., Gualtierotti, R., Griffini, S., Grovetti, E., Torri, A., et al. (2021). 565 Complement activation and endothelial perturbation parallel COVID-19 severity and activity.

566 J. Autoimmun. 116, 102560. doi: 10.1016/j.jaut.2020.102560 
medRxiv preprint doi: https://doi.org/10.1101/2021.10.17.21265108; this version posted October 18, 2021. The copyright holder for this preprint (which was not certified by peer review) is the author/funder, who has granted medRxiv a license to display the preprint in perpetuity.

It is made available under a CC-BY-NC-ND 4.0 International license .

567 Demelo-Rodriguez, P., Cervilla-Munoz, E., Ordieres-Ortega, L., Parra-Virto, A., Toledano-

568 Macias, M. et al. (2020). Influence of asymptomatic deep vein thrombosis in patients with

569 COVID-19 pneumonia and elevated D-dimers levels. Thrombosis Res. 192, 23-26. doi:

$570 \quad 10.1016 /$ j.thromres.2020.05.018

571 Di Micco, P., Russo, V., Carannante, N., Imparato, M., Cardillo, G., and Lodigiani, C.

572 (2020). Prognostic value of fibrinogen among COVID-19 patients admitted to an emergency

573 department: an Italian cohort study. J. Clin. Med. 9, 4134. doi: 10.3390/jcm9124134

574 Di Minno, M.N.D., Calcaterra, I., Lupoli, R., Storino, A., Spedicato, G.A., Maniscalco, M. et

575 al. (2020) Hemostatic changes in patients with COVID-19: a meta-analysis with meta-

576 regressions. J. Clin. Med. 9, 2244; doi:10.3390/jcm9072244

577 Ding, R., Yang, Z., Huang, D., Wang, Y., Li, X., Zhou, X., et al. (2021). Identification of

578 parameters in routine blood and coagulation tests related to the severity of COVID-19. Int. J.

579 Med. Sci. 18, 1207-1215. doi: 10.7150/ijms.47494

580 Doevelaar, A. A., Bachmann, M., Hölzer, B., Seibert, F. S., Rohn, B. J., Bauer, F., et al.

581 (2021). Von Willebrand factor multimer formation contributes to immunothrombosis in

582 Coronavirus disease 2019. Critical Care Med. 49, e512-e520. doi:

583 10.1097/CCM.0000000000004918

584 Fan, B. E., Ng, J., Chan, S.S.W., Christopher, D., Tso, A.C.E., Ling, A.M. et al. (2021).

585 COVID-19 associated coagulopathy in critically ill patients: A hypercoagulable state 586 demonstrated by parameters of haemostasis and clot waveform analysis. J. Thromb.

587 Thrombolysis 51, 663-674. doi.org/10.1007/s11239-020-02318-x 
medRxiv preprint doi: https://doi.org/10.1101/2021.10.17.21265108; this version posted October 18, 2021. The copyright holder for this preprint (which was not certified by peer review) is the author/funder, who has granted medRxiv a license to display the preprint in perpetuity.

It is made available under a CC-BY-NC-ND 4.0 International license .

588 Feld, L., Belfer, J., Kabra, R., Goenka, P., Rai, S., Moriarty, S., et al. (2020). A case series of 589 the 2019 novel coronavirus (SARS-CoV-2) in 3 febrile infants in New York. Pediatrics.146, 590 e20201056. doi: 10.1542/peds.2020-1056

591 Fox, S.E., Akmatbekov, A., Harbert, J.L., Li, G., Brown, J.Q., and Vander Heide, R.S. 592 (2020). Pulmonary and cardiac pathology in African American patients with COVID-19: an 593 autopsy series from New Orleans. Lancet Respir. Med. 8, 681-686. doi: 10.1016/S2213$594 \quad 2600(20) 30243-5$

595 Fu, J., Kong, J., Wang, W., Wu, M., Yao, L., Wang, Z., et al. (2020). The Clinical 596 implication of dynamic neutrophil to lymphocyte ratio and D-dimer in COVID-19: a 597 retrospective study in Suzhou China. Thromb. Res. 192, 3-8. doi: $598 \quad 10.1016 / j$. thromres.2020.05.006

599 Garaci, F., Di Giuliano, F., Picchi, E., Da Ros, V., and Floris, R. (2020). Venous cerebral 600 thrombosis in COVID-19 patient. J. Neurol. Sci. 414, 116871. doi: $601 \quad$ 10.1016/j.jns.2020.116871

602 Gerotziafas, G. T., Sergentanis, T. N., Voiriot, G., Lassel, L., Papageorgiou, C., Elabbadi, A., 603 et al. (2020). Derivation and validation of a predictive score for disease worsening in patients 604 with COVID-19. Thromb. Haemost. 120, 1680-1690. doi: 10.1055/s-0040-1716544

605 Giannis, D., Ziogas, I.A., and Gianni, P. (2020). Coagulation disorders in coronavirus 606 infected patients: COVID-19, SARS-CoV-1, MERS-CoV and lessons from the past. J. Clin. 607 Virol. 127, 104362. doi: 10.1016/j.jcv.2020.104362

608 Goeijenbier, M., Van Wissen, M., Van De Weg, C., Jong, E., Gerdes, V. E. A., Meijers, J. C. 609 M., et al. (2012). Review: viral infections and mechanisms of thrombosis and bleeding. J. 610 Med. Virol. 84, 1680-1696. doi: 10.1002/jmv.23354 
611 Goodwin, A.J., Higgins, R.A., Moser, K.A., Smock, K.J., Chandler, V.L., Kottke-Marchant,

612 K., et al. (2017). Issues surrounding age-adjusted D-dimer cutoffs that practicing physicians

613 need to know when evaluating patients with suspected pulmonary embolism. Ann. Intern.

614 Med. 166, 361-364. doi: 10.7326/M16-2030

615 Goshua, G., Pine, A.B., Meizlish, M.L., Chang, C.-H., Zhang, H., Bahel, P. et al (2020).

616 Endotheliopathy in COVID-19-associated coagulopathy: evidence from a single-centre, 617 cross-sectional study. Lancet Haematol. 7, e575-e582. doi: 10.1016/S2352 3026(20)30216-7

618 Grillet, F., Behr, J., Calame, P., Aubry, S., and Delabrousse, E. (2020). Acute pulmonary 619 embolism associated with COVID-19 pneumonia detected by pulmonary CT angiography. 620 Radiology. 23, 201544. doi: 10.1148/radiol.2020201544

621 Guervilly, C., Burtey, S., Sabatier, F., Cauchois, R., Lano, G., Abdili, E., et al. (2020). 622 Circulating endothelial cells as a marker of endothelial injury in severe COVID-19. J. Infect. 623 Dis. 222, 1789-1793. doi: 10.1093/infdis/jiaa528

624 Guthikonda, S., Lev, E.I., Patel, R., DeLao, T., Bergeron, A.L., Dong, J.F., et al. (2007) 625 Reticulated platelets and uninhibited COX-1 and COX-2 decrease the antiplatelet effects of 626 aspirin. J. Thromb. Haemost. 5, 490-496. doi:10.1111/j.1538-7836.2007.02387.x

627 Helms, J., Tacquard, C., Severac, F., Leonard-Lorant, I., Ohana, M., Delabranche, X., et al. 628 (2020). High risk of thrombosis in patients with severe SARS-CoV2-infection: a multicenter 629 prospective cohort study. Intens. Care Med. 46, 1089-1098. doi: 10.1007/s00134- 020-06062$630 \mathrm{x}$

631 Higuera-de-la-Tijera, F., Servín-Caamaño, A., Reyes-Herrera, D., Flores-López, A., Robiou 632 Vivero, E., Martínez-Rivera, F., et al. (2021). The Age-AST-D Dimer (AAD) regression 
medRxiv preprint doi: https://doi.org/10.1101/2021.10.17.21265108; this version posted October 18, 2021. The copyright holder for this preprint (which was not certified by peer review) is the author/funder, who has granted medRxiv a license to display the preprint in perpetuity.

It is made available under a CC-BY-NC-ND 4.0 International license .

633 model predicts severe COVID-19 disease. Dis. Markers. 2021:6658270. doi:

$634 \quad 10.1155 / 2021 / 6658270$

635 Holter, J.C., Pischke, S.E., de Boer, E., Lind, A., Jenum, S., Holten, A.R. et al. (2020).

636 Systemic complement activation is associated with respiratory failure in COVID-19 patients.

637 Proc. Natl. Acad. USA 117, 25018-25025

638 Hottz, E.D., Azevedo-Quintanilha, I.G., Palhinha, L., Teixeira, L., Barretto, E.A., Pao,

639 C.R.R. et al. (2020). Platelet activation and platelet-monocyte aggregate formation trigger

640 tissue factor expression in patients with severe COVID-19. Blood 136, 1330-1341.

641 https://doi.org/10.1182/blood.2020007252

642 Huang, C., Wang, Y., Li, X., Ren, L., Zhao, J., Hu, Y., et al. (2020). Clinical features of 643 patients infected with 2019 novel coronavirus in Wuhan, China. Lancet 395, 10223. doi: $644 \quad 10.1016 / \mathrm{s} 0140-6736(20) 30183-5$

645 Hulshof, A.-M., Brueggemann, R.A.G., Mulder, M.M.G., van de Berg, T.W., Sels, J.-W. 646 E.M., Olie, R.H. (2021) Serial EXTEM, FIBTEM, and tPA Rotational thromboelastometry 647 observations in the Maastricht Intensive Care COVID Cohort - persistence of 648 hypercoagulability and hypofibrinolysis despite anticoagulation. Front. Cardiovasc. Med. 8, 649 654174. doi: 10.3389/fcvm.2021.654174

650 Hunt, B.J., Levi, M. (2020). The source of elevated plasma D-dimer levels in COVID-19 651 infection. Br. J. Haematol. doi: 10.1111/bjh.16907

652 Hwang, D. M., Chamberlain, D. W., Poutanen, S. M., Low, D. E., Asa, S. L., and Butany, J. 653 (2005). Pulmonary pathology of severe acute respiratory syndrome in Toronto. Modern. 654 Pathol. 18, 1-10. doi: 10.1038/modpathol.3800247 
medRxiv preprint doi: https://doi.org/10.1101/2021.10.17.21265108; this version posted October 18, 2021. The copyright holder for this preprint (which was not certified by peer review) is the author/funder, who has granted medRxiv a license to display the preprint in perpetuity.

It is made available under a CC-BY-NC-ND 4.0 International license .

655 Iba, T., Levy, J.H., Levi, M., Connors, J.M., and Thachil, J. (2020). Coagulopathy of

656 coronavirus disease-2019. Crit. Care. Med. 48, 1358-1364. doi:

$657 \quad 10.1097 /$ CCM.0000000000004458

658 Ibrahim, H., Nadipalli, S., DeLao, T., Guthikonda, S., Kleiman, N.S. (2012) Immature

659 platelet fraction (IPF) determined with an automated method predicts clopidogrel

660 hyporesponsiveness. J. Thromb. Thrombolysis 33, 137-42. doi:10.1007/s11239-011-0665-7.

661 Johns Hopkins University \& Medicine (2021). The Johns Hopkins Coronavirus Resource

662 Center (CRC). https://coronavirus.jhu.edu/ [Accessed September 30, 2021].

663 Karakoyun, I., Colak, A., Turken, M., Altin, Z., Arslan, F. D., Iyilikci, V., et al. (2021).

664 Diagnostic utility of C-reactive protein to albumin ratio as an early warning sign in 665 hospitalized severe COVID-19 patients. Int. Immunopharmacol. 91, 107285. doi: $666 \quad$ 10.1016/j.intimp.2020.107285

667 Klok, F.A., Kruip, M.J.H.A., Van der Meer, N.J.M., Arbous, M.C., Gommers, D.A.M.P.J. et 668 al. (2020). Incidence of thrombotic complications in critically ill ICU patients with COVID669 19. Thrombosis Res. 191, 145-147. doi: 10.1016/j.thromres.2020.04.013

670 Krishnamachary, B., Cook, S., Kumar, A., Spikes, L., Chalise, P., Dhillon, N.K. (2021)

671 Extracellular vesicle-mediated endothelial apoptosis and EV-associated proteins correlate 672 with COVID-19 disease severity. J. Extracel. Vesicles. 10, e12117. doi: 10.1002/jev2.12117

673 Kunutsor, S.K., and Laukkanen, J.A. (2020). Incidence of venous and arterial 674 thromboembolic complications in COVID-19: a systematic review and meta-analysis.

675 Thrombosis Res. 196, 27-30. doi: 10.1016/j.thromres.2020.08.022 
medRxiv preprint doi: https://doi.org/10.1101/2021.10.17.21265108; this version posted October 18, 2021. The copyright holder for this preprint (which was not certified by peer review) is the author/funder, who has granted medRxiv a license to display the preprint in perpetuity.

It is made available under a CC-BY-NC-ND 4.0 International license .

676 Lee, N., Hui, D., Wu, A., Chan, P., Cameron, P., Joynt, G.M., et al. (2003). A major outbreak

677 of severe acute respiratory syndrome in Hong Kong. N. Engl. J. Med. 348, 1986-94.

678 https://doi.org/10.1056/NEJMoa030685

679 Levi, M., and Scully, M. (2018). How I treat disseminated intravascular coagulation. Blood.

680 131, 845-854. doi: 10.1182/blood-2017-10-804096

681 Levi, M., Thachil, J., Iba, T., Levi, J.H. (2020). Coagulation abnormalities and thrombosis in

682 patients with COVID-19. Lancet Haematol. 7, e438-440. doi: 10.1016/ S2352-

$683 \quad 3026(20) 30145-9$

684 Liao, D., Zhou, F., Luo, L., Xu, M., Wang, H., Xia, J., et al. (2020). Haematological 685 characteristics and risk factors in the classification and prognosis evaluation of COVID-19: a 686 retrospective cohort study. Lancet Haematol. 7, e671-e678. doi: 10.1016/s2352$687 \quad 3026(20) 30217-9$

688 Lippi, G., Plebani, M., and Henry, B.M. (2020). Thrombocytopenia is associated with severe 689 coronavirus disease 2019 (COVID-19) infections: a meta-analysis. Clin. Chim. Acta 506, 690 145-148. doi:10.1016/j. cca.2020.03.022

691 Lippi, G., Henry, B.M., Favaloro, E.J. (2021). Mean platelet volume predicts severe COVID69219 illness. $\quad$ Semin. $\quad$ Thromb. Hemost. 47, 456-459

693 DOI: $10.1055 / \mathrm{s}-0041-1727283$

694 Liu, J., Liu, Z., Jiang, W., Wang, J., Zhu, M., Song, J., et al. (2020a). Clinical predictors of 695 COVID-19 disease progression and death: analysis of 214 hospitalized patients from Wuhan, 696 China. Clin. Res. J. 15, 293-309. doi: 10.1111/crj.13296 
medRxiv preprint doi: https://doi.org/10.1101/2021.10.17.21265108; this version posted October 18, 2021. The copyright holder for this preprint (which was not certified by peer review) is the author/funder, who has granted medRxiv a license to display the preprint in perpetuity.

It is made available under a CC-BY-NC-ND 4.0 International license .

697 Liu, J., Zhang, S., Wu, Z., Shang, Y., Dong, X., Li, G., et al. (2020b). Clinical outcomes of 698 COVID-19 in Wuhan, China: a large cohort study. Ann. Intensive Care. 10, 1-21. doi: 699 $10.1186 / \mathrm{s} 13613-020-00706-3$

Liu, J., Tu, C., Zhu, M., Wang, J., Yang, C., Liu, W., and Xiong, B. (2021). The Clinical course and prognostic factors of severe COVID-19 in Wuhan, China. Medicine. 100: e23996. doi: 10.1097/md.0000000000023996

Liu, W., Tao, Z. W., Wang, L., Yuan, M. L., Liu, K., Zhou, L., et al. (2020). Analysis of factors associated with disease outcomes in hospitalized patients with 2019 novel coronavirus disease. Chin. Med. J. 133, 1032-1038. doi: 10.1097/cm9.0000000000000775

Llitjos, J.-F., Leclerc, M., Chochois, C., Monsallier, J.-M., Ramakers, M., Auvray, M., et al. (2020). High incidence of venous thromboembolic events in anticoagulated severe COVID19 patients. J. Thromb. Haemost. 18, 1743-1746. doi: 10.1111/jth.14869

Lodigiani, C., Iapichino, G., Carenzo, L., Cecconi, M., Ferrazzi, P., Sebastian, T., et al. (2020). Venous and arterial thromboembolic complications in COVID $\square 19$ patients admitted to an academic hospital in Milan, Italy. Thromb. Res. 191, 9-14. doi: 10.1016/j.thromres.2020.04.024

Long, H., Nie, L., Xiang, X., Li, H., Zhang, X., Fu, X., et al. (2020). D-Dimer and prothrombin time are the significant indicators of severe COVID-19 and poor prognosis. Biomed. Res. Int. 2020, 6159720. doi: 10.1155/2020/6159720

Lopez-Castaneda, S., García-Larragoiti, N., Cano-Mendez, A., Blancas-Ayala, K., DamianVázquez, G., Perez-Medina, A. I., et al. (2021). Inflammatory and prothrombotic biomarkers associated with the severity of COVID-19 infection. Clin. Appl. Thromb. Hemost. 27, 1-9. doi: $10.1177 / 1076029621999099$ 
medRxiv preprint doi: https://doi.org/10.1101/2021.10.17.21265108; this version posted October 18, 2021. The copyright holder for this preprint (which was not certified by peer review) is the author/funder, who has granted medRxiv a license to display the preprint in perpetuity.

It is made available under a CC-BY-NC-ND 4.0 International license .

720 Luo, D., Wan, X., Liu, J., and Tong, T. (2018). Optimally estimating the sample mean from

721 the sample size, median, mid-range, and/or mid-quartile range. Stat. Meth. Med. Res. 27,

$722 \quad 1785-1805$. doi: 10.1177/0962280216669183

723 Luo, L., Xu, M., Du, M., Kou, H., Liao, D., Cheng, Z., et al. (2020). Early coagulation tests

724 predict risk stratification and prognosis of COVID-19. Aging (Albany NY). 12, 15918-

725 15937. doi: 10.18632/aging. 103581

726 Mikami, T., Miyashita, H., Yamada, T., Harrington, M., Steinberg, D., Dunn, A., and Siau, E.

727 (2021). Risk factors for mortality in patients with COVID-19 in New York City. J. Gen.

728 Intern. Med. 36, 17-26. doi: 10.1007/s11606-020-05983-z

729 Monteil, V., Kwon, H., Prado, P., Hagelkrüys, A., Wimmer, R. A., Stahl, M., et al. (2020).

730 Inhibition of SARS-CoV-2 infections in engineered human tissues using clinical-grade

731 soluble human ACE2. Cell 181, 905-913. doi: 10.1016/j.cell.2020.04.004

732 National Heart, Lung, and Blood Institute. (2019). Study quality assessment tools.

733 https://www. nhlbi. nih. gov/health-topics/study-quality-assessment-tools [Accessed

734 September $\left.20^{\text {th }}, 2021\right]$.

735 Noh, C. S., Kim, W. Y., and Baek, M. S. (2021). Risk factors associated with the need for

736 oxygen therapy in patients with COVID-19. Medicine. 100, e25819. doi:

$737 \quad 10.1097 / \mathrm{md} .0000000000025819$

738 Nougier, C., Benoit, R., Simon, M., Desmurs-Clavel, H., Marcotte, G., Argaud. L., et al.

739 (2020) Hypofibrinolytic state and high thrombin generation may play a major role in SARS-

740 Cov2 associated thrombosis. J. Thromb. Haemost. 18, 2215-2219. doi: 10.1111/jth.15016 
medRxiv preprint doi: https://doi.org/10.1101/2021.10.17.21265108; this version posted October 18, 2021. The copyright holder for this preprint (which was not certified by peer review) is the author/funder, who has granted medRxiv a license to display the preprint in perpetuity.

It is made available under a CC-BY-NC-ND 4.0 International license .

741 Olson, J.D., Cunningham, M.T., Higgins, R.A., Eby, C.S., and Brandt, J.T. (2013). D-dimer:

742 simple test, tough problems. Arch. Pathol. Lab. Med. 137, 1030-1038.

743 doi:10.5858/arpa.2012-0296-CP

744 Panigada, M., Bottino, N., Tagliabue, P., Grasselli, G., Novembrino, C., Chantarangkul, V., 745 et al. (2020). Hypercoagulability of COVID-19 patients in intensive care unit: a report of 746 thromboelastograpgy and other parameters of hemostasis. J. Thromb. Haemost. 18, 1738747 1742. doi: $10.1111 /$ jth. 14850

748 Pavoni, V., Gianesello, L., Pazzi, M., Stera, C., Meconi, T., Frigieri, F.C. (2020) Evaluation 749 of coagulation function by rotation thromboelastometry in critically ill patients with severe 750 COVID-19 pneumonia. J. Thromb. Thrombolysis. 50, 281-286. doi: 10.1007/s11239-020$751 \quad 02130-7$

752 Piazza, G., Campia, U., Hurwitz, S., Snyder, J. E., Rizzo, S. M., Pfeferman, M. B., et al. 753 (2020). Registry of arterial and venous thromboembolic complications in patients with 754 COVID-19. J. Am. Coll. Cardiol. 76, 2060-2072. doi: 10.1016/j.jacc.2020.08.070

755 Pustejovsky, M.A., and Rodgers, J.E. (2019). Testing for funnel plot asymmetry of 756 standardized mean differences. Res. Synthesis Meth. 10, 57-71. doi: 10.1002/jrsm.1332

757 Qu, R., Ling, Y., Zhang, Y.H.Z., Wei, L.Y., Chen, X., Li, X.M. et al. (2020). Platelet-to 758 lymphocyte ratio is associated with prognosis in patients with coronavirus disease-19. J. Med.

759 Virol. 92, 1533-1541. doi: 10.1002/jmv.25767

760 Ranucci, M., Ballotta, A., Di Dedda, U., Bayshnikova, E., Dei Poli, M., Resta, M., et al. 761 (2020). The procoagulant pattern of patients with COVID-19 acute distress syndrome. J. 762 Thromb. Haemost. 18, 1747-1751. doi: 10.1111/jth.14854 
medRxiv preprint doi: https://doi.org/10.1101/2021.10.17.21265108; this version posted October 18, 2021. The copyright holder for this preprint (which was not certified by peer review) is the author/funder, who has granted medRxiv a license to display the preprint in perpetuity.

It is made available under a CC-BY-NC-ND 4.0 International license .

763 Rauch, A., Labreuche, J., Lassalle, F., Goutay, J., Caplan, M., Charbonnier, L., et al. (2020).

764 Coagulation biomarkers are independent predictors of increased oxygen requirements in

765 COVID-19. J. Thromb. Haemost. 18, 2942-2953. doi: 10.1111/jth.15067

766 Shang, W., Dong, J., Ren, Y., Tian, M., Li, W., Hu, J., et al. (2020). The value of clinical

767 parameters in predicting the severity of COVID-19. J. Med. Virol. 92, 2188-2192. doi:

$768 \quad 10.1002 / j m v .26031$

769 Spyropoulos, A. C., Levy, J. H., Ageno, W., Connors, J. M., Hunt, B. J., Iba, T., et al. (2020).

770 Scientific and standardization committee communication: clinical guidance on the diagnosis,

771 prevention and treatment of venous thromboembolism in hospitalized patients with COVID-

772 19. J. Thromb. Haemost. 18, 1859-1865. doi: 10.1111/jth.14929

773 Suleyman, G., Fadel, R. A., Malette, K. M., Hammond, C., Abdulla, H., Entz, A., et al.

774 (2020). Clinical characteristics and morbidity associated with coronavirus disease-2019 in a

775 series of patients in metropolitan Detroit. JAMA Netw. Open. 3, e2012270. doi: 715

776 10.1001/jamanetworkopen.2020.12270

777 Tang, N., Li, D., Wang, X., and Sun, Z. (2020). Abnormal coagulation parameters are 778 associated with poor prognosis in patients with novel coronavirus pneumonia. J. Thromb.

779 Haemost. 18, 844-847. doi: 10.1111/jth.14768

780 Thachil, J., Tang, N., Gando, S., Falanga, A., Cattaneo, M., Levi, M., et al. (2020). ISTH 781 interim guidance on recognition and management of coagulopathy in COVID-19. J. Thromb.

782 Haemost. 18, 1023-1026. doi: 10.1111/jth.14810

783 Thoreau,B., Galland, J., Delrue, M., Neuwirth, M., Stepanian, A., Chauvin, A. et al. (2021).

784 D-Dimer levels and neutropils count as predictive and prognostic factors of pulmonary 
medRxiv preprint doi: https://doi.org/10.1101/2021.10.17.21265108; this version posted October 18, 2021. The copyright holder for this preprint (which was not certified by peer review) is the author/funder, who has granted medRxiv a license to display the preprint in perpetuity.

It is made available under a CC-BY-NC-ND 4.0 International license .

785 embolism in severe non-ICU COVID-19 patients. Viruses. 13, 758. doi: 725 $786 \quad 10.3390 / \mathrm{v} 13050758$

787 Van der Meijden, P.E.J., Heemskerk, J.W.M. (2019) Platelet biology and functions: new

788 concepts and clinical perspectives. Nature Rev. Cardiol. 16, 166-179.

789 https://doi.org/10.1038/s41569-018-0110-0

790 Varga, Z., Flammer, A. J., Steiger, P., Haberecker, M., Andermatt, R., Zinkernagel, A. S., et

791 al. (2020). Endothelial cell infection and endotheliitis in COVID-19. Lancet 395, 1417-1418.

792 doi: 10.1016/S0140-6736(20)30937-5

793 Veroniki, A. A., Jackson, D., Viechtbauer, W., Bender, R., Bowden, J., Knapp, G., et al. 794 (2016). Methods to estimate the between-study variance and its uncertainty in meta-analysis. 795 Res. Synth. Methods. 7, 55-79. doi: 10.1002/jrsm.1164

796 Wang, D., Hu, B., Hu, C., Zhu, F., Liu, X., Zhang, J., et al. (2020). Clinical characteristics of 797138 hospitalized patients with 2019 novel coronavirus-infected pneumonia in Wuhan, China. $798 \quad$ JAMA. 323, 1061-1069. doi: 10.1001/jama.2020.1585

799 Wan, X., Wang, W., Liu, J., and Tong, T. (2014). Estimating the Sample Mean and Standard 800 Deviation from the Sample Size, Median, Range and/or Interquartile range. BMC Med. Res. 801 Methodol. 14, 1-13. doi: 10.1186/1471-2288-14-135

802 Wang, P., Sha, J., Meng, M., Wang, C., Yao, Q., Zhang, Z., et al. (2020). Risk factors for 803 severe COVID-19 in middle-aged patients without comorbidities: a multicentre retrospective 804 study. J. Transl. Med. 18, 1-12. doi: 10.1186/s12967-020-02655-8

805 Wang, Y., Yao, L., Zhang, J. P., Tang, P. J., Ye, Z. J., Shen, X. H., et al. (2020). Clinical 806 characteristics and laboratory indicator analysis of 67 COVID-19 pneumonia patients in 807 Suzhou, China. BMC Infect. Dis. 20,747. doi: 10.1186/s 12879-020-05468-8 
medRxiv preprint doi: https://doi.org/10.1101/2021.10.17.21265108; this version posted October 18, 2021. The copyright holder for this preprint (which was not certified by peer review) is the author/funder, who has granted medRxiv a license to display the preprint in perpetuity.

It is made available under a CC-BY-NC-ND 4.0 International license .

808 Welder, D., Jeon-Slaughter, H., Ashraf, B., Choi, S.-H., Chen, W., Ibrahim, I. et al. (2021).

809 Immature platelets as a biomarker for disease severity and mortality in COVID-19 patients.

810 Br. J. Haem. 194, 530-536. https://doi.org/10.1111/bjh.17656

811 White, D., MacDonald, S., Edwards, T., Bridgeman, C., Hayman, M., Sharp, M., et al. 812 (2020). Evaluation of COVID-19 coagulopathy: laboratory characterization using thrombin 813 generation and nonconventional haemostasis assays. Int. J. Lab. Hematol. 43, 123-130. doi: $814 \quad 10.1111 /$ ijlh.13329

815 Wong, R.S., Wu, A., To, K.F., Lee, N, Lam, C.W., Wong, C.K., et al. (2003). 816 Haematological manifestations in patients with severe acute respiratory syndrome: 817 retrospective analysis. Br. Med. J. 326, 1358- 62.

818 World Health Organization. (2013). Guidelines for investigation of cases of human infection 819 with Middle East Respiratory Syndrome Coronavirus (MERS-CoV).

820 (https://cdn.who.int/media/docs/default-source/documents/emergencies/health-topics---

821 mers/mers_cov_investigation_guideline_jul132d7b61a0-a593-4527-8246-

822 25152b965baf.pdf?sfvrsn=3e2f6c65_1\&download=true [Accessed September 30, 2021]

823 Wright, F.L., Vogler, T.O., Moore, E.E., Moore, H.B., Wohlauer, M.V., Urban, S., et al. 824 (2020). Fibrinolysis shutdown correlation with thromboembolic events in severe COVID-19 825 infection. J. Amer. Col. Surgeons. 231, 193-203. doi: 10.1016/j.jamcollsurg.2020.05.007

826 Xiong, M., Liang, X., and Wei Y.D. (2020). Changes in blood coagulation in patients with 827 severe coronavirus disease 2019 (COVID-2019): a meta-analysis. Br. J. Haem. 189, 1050828 1052. doi: 10.1111/bjh. 16725

829 Yang, M., Ng, M. H., and Li, C. K. (2005). Thrombocytopenia in patients with severe acute 830 respiratory syndrome. Hematology 10, 101-105. doi: 10.1080/10245330400026170 
medRxiv preprint doi: https://doi.org/10.1101/2021.10.17.21265108; this version posted October 18, 2021. The copyright holder for this preprint (which was not certified by peer review) is the author/funder, who has granted medRxiv a license to display the preprint in perpetuity.

It is made available under a CC-BY-NC-ND 4.0 International license .

831 Yang, X., Yang, Q., Wang, Y., Wu, Y., Xu, J., Yu, Y., et al. (2020). Thrombocytopenia and

832 its association with mortality in patients with COVID-19. J. Thromb. Haemost. 18, 1469-72.

833 doi: $10.1111 /$ jth. 14848

834 Yasuhara, J., Kuno, T., Takagi, H., and Sumitomo, N. (2020). Clinical characteristics of

835 COVID 19 in children: a systematic review. Pediatr. Pulmonol. 55, 2565-2575. doi:

$836 \quad 10.1002 / p p u l .24991$

837 Yatim, N., Boussier, J., Chocron, R., Hadjadj, J., Philippe, A., Gendron, N. (2021). Platelet

838 activation in critically ill COVID-19 patients. Ann. Intensive Care 11, 113.

839 doi.org/10.1186/s13613-021-00899-1

840 Young, B. E., Ong, S. W. X., Kalimuddin, S., Low, J. G., Tan, S. Y., Loh, J., et al. (2020).

841 Epidemiologic features and clinical course of patients infected with SARS-CoV-2 in

842 Singapore. JAMA 323, 1488-1494. doi: 10.1001/jama.2020.3204

843 Yu, C., Lei, Q., Li, W., Wang, X., Li, W., and Liu, W. (2020). Epidemiological and clinical

844 characteristics of 1663 hospitalized patients infected with COVID-19 in Wuhan, China: a

845 single-center experience. J. Infect. Public Health. 13, 1202-1209. doi:

$846 \quad 10.1016 /$ j.jiph.2020.07.002

847 Yue, T., Zhou, W., He, J., Wang, H., Liu, Y., Wang, B., et al. (2021). Combined clinical and

848 imaging features better predict the critical outcomes of patients with SARS-COV-2. Medicine

849 100, e25083. doi: 10.1097/md.0000000000025083

850 Zhang, A., Leng, Y., Zhang, Y., Wu, K., Ji, Y., Lei, S., et al. (2020). Meta-analysis of 851 coagulation parameters associated with disease severity and poor prognosis of COVID-19.

852 Inter. J. Infect. Dis. 100, 441-448. doi: 10.1016/j.ijid.2020.09.021 
medRxiv preprint doi: https://doi.org/10.1101/2021.10.17.21265108; this version posted October 18, 2021. The copyright holder for this preprint (which was not certified by peer review) is the author/funder, who has granted medRxiv a license to display the preprint in perpetuity.

It is made available under a CC-BY-NC-ND 4.0 International license .

853 Zhang, H., Wang, X., Fu, Z., Luo, M., Zhang, Z., Zhang, K., et al. (2020). Potential factors

854 for prediction of disease severity of COVID-19 patients. medRxiv [Preprint]. doi:

$855 \quad 10.1101 / 2020.03 .20 .20039818$

856 Zhang, J., Huang, X., Ding, D., and Tao, Z. (2021). Platelet-driven coagulopathy in COVID-

85719 patients: in comparison to seasonal influenza cases. Exp. Hematol. Oncol. 10, 1-13. doi:

$858 \quad 10.1186 / \mathrm{s} 40164-021-00228-\mathrm{Z}$

859 Zhao, J., Zhu, M., Su, X., Huang, M., Yang, Y., Huang, J., et al. (2021). Clinical features and

860 risk factors for severe-critically ill COVID-19 adult patients in Jiangsu, China. Medicine.

861 100, e24332. doi: 10.1097/md.0000000000024332

862 Zhao, Y., Yu, C., Ni, W., Shen, H., Qiu, M., and Zhao, Y. (2021). Peripheral blood

863 inflammatory markers in predicting prognosis in patients with COVID-19. Some differences

864 with Influenza A. J. Clin. Lab. Anal. 35, e23657. doi: 10.1002/jcla.23657

865 Zheng, X., Chen, J., Deng, L., Fang, Z., Chen, G., Ye, D., et al. (2020). Risk factors for the

866 COVID-19 severity and its correlation with viral shedding: a retrospective cohort study. Int.

867 J. Infect. Dis. 93, 952-961. doi: 10.1002/jmv.26367

868 Zhou, C., Huang, Z., Tan, W., Li, X., Yin, W., Xiao, Y., et al. (2020). Predictive factors of

869 severe coronavirus disease-2019 in previously healthy young adults: a single-center,

870 retrospective study. Respir. Res. 21:157, 1-8. doi: 10.1186/s12931-020-01412-1

871 Zhu, J., Pang, J., Ji, P., Zhong, Z., Li, H., Li, B. et al. (2020) Coagulation disfunction is 872 associated with a severity of COVID-19. J. Med. Virol. 93, 962-972. doi: 10.1002/jmv.26336

873 Zwetsloot, P.-P., Naald, M.V.D., Sena, E.S., Howells, W.D., IntHout, J., De Groot, J.A.H. et

874 al. (2017). Standardized means differences cause funnel plots distortion in publication bias

875 assessments. eLife 6, e24260 DOI: 10.7554/eLife.24260 


\section{Legends to the Tables}

877 Table 1. Summary of the effect sizes for all coagulation parameters

878 Table 2. Summary results of the sensitivity analysis

879 Table 3. Summary results of the subgroup analysis

880 Table 4. Egger's test for publication bias

881

883 Legends to the Figures

884 Figure 1. Flow diagram illustrating the process of data collection

885 Figure 2. Diagram depicting characteristics of selected studies: (A) number of publications 886 per country; (B) number of patients per country; (C) number of publications per severity 887 assessment criterion. The latter $(\mathbf{C})$ indicates the total number of research articles to be 42 888 instead of 41 because one study reported two populations of patients admitted to the hospital 889 at different periods.

890 Figure 3. Forest plot of association between COVID-19 severity and (A) platelets; (B) D891 dimers

892

Figure 4. Forest plots of the association between COVID-19 severity and (A) fibrinogen; (B) activated partial thromboplastin time; $(\mathbf{C})$ prothrombin time.

894 Figure 5. GOSH diagnostic for influential cases in meta-analysis models (A) PLT; (B) D895 dimers.

896 Figure 6. GOSH plots fixed for influential studies in meta-analysis models (A-B) 897 fibrinogen; (C-E) - APTT, (F-I) - prothrombin time. 
898 Figure 7. Contour-enhanced funnel plots evaluating the presence of publication bias in the 899 pool of articles that report association between COVID-19 severity and (A) platelets; (B) D900 dimers; (C) fibrinogen; (D) activated partial thromboplastin time; (E) prothrombin time.

901

902

\section{Legends to Supplementary Materials}

904 Supplementary File 1. Criteria for clinical severity of COVID-19 used by the National 905 Research Center for Cardiac Surgery.

906 Supplementary Table 1. Results of the NIH Quality Assessment.

907 Supplementary Table 2. Results of the Egger's test with Pustejovsky's corrected standard 908 error.

909 Supplementary Figure 1. Exploring influential cases in meta-analysis models with Baujat 910 plots: (A) Platelets, (B) D-dimers, (C) Fibrinogen, (D) Activated partial thromboplastin time, 911 (E) Prothrombin time.

912 Supplementary Figure 2. Influence diagnostic of meta-analysis model for the association of 913 platelets count and COVID-19 severity.

914 Supplementary Figure 3. Influence diagnostic of meta-analysis model for the association of 915 D-dimers concentration and COVID-19 severity.

916 Supplementary Figure 4. Influence diagnostic of meta-analysis model for the association of 917 fibrinogen and COVID-19 severity. 
918 Supplementary Figure 5. Influence diagnostic of meta-analysis model for the association of activated partial thromboplastin time and COVID-19 severity.

920 Supplementary Figure 6. Influence diagnostic of meta-analysis model for the association of 921 prothrombin time and COVID-19 severity.

Supplementary Figure 7. Search for influential cases by leave-one-out method in metaanalysis models for the association of (A) platelets count, (B) D-dimers and COVID-19 severity.

925 Supplementary Figure 8. Search for influential cases by leave-one-out method in meta926 analysis models for the association of (A) fibrinogen, (B) APTT and COVID-19 severity.

927 Supplementary Figure 9. Search for influential cases by leave-one-out method in meta928 analysis model for the association of prothrombin time and COVID-19 severity.

929 Supplementary Figure 10. Forest plots of association of COVID-19 severity and (A) 930 platelets count and (B) D-dimers with outliers removed.

931 Supplementary Figure 11. Forest plots of association of COVID-19 severity and (A) 932 fibrinogen, (B) activated partial thromboplastin time, and (C) prothrombin time with outliers 933 removed.

934 Supplementary Figure 12. Exploring the influence of meta-analysis study composition on 935 heterogeneity and pooled effect size: (A) fibrinogen, (B) activated partial thromboplastin 936 time, and (C) prothrombin time.

937 Supplementary Figure 13. Results of three clustering methods (A) K-means, (B) DBSCAN, 938 and (C) Gaussian Mixture on the meta-analysis model for association of fibrinogen and 939 COVID-19 severity. 
medRxiv preprint doi: https://doi.org/10.1101/2021.10.17.21265108; this version posted October 18, 2021. The copyright holder for this preprint

(which was not certified by peer review) is the author/funder, who has granted medRxiv a license to display the preprint in perpetuity.

It is made available under a CC-BY-NC-ND 4.0 International license.

940 Supplementary Figure 14. Results of three clustering methods (A) K-means, (B) DBSCAN,

941 and (C) Gaussian Mixture on the meta-analysis model for association of activated partial

942 thromboplastin time and COVID-19 severity.

943 Supplementary Figure 15. Results of three clustering methods (A) K-means, (B) DBSCAN,

944 and (C) Gaussian Mixture on the meta-analysis model for association of prothrombin time 945 and COVID-19 severity.

946 Supplementary Figure 16. Exploring presence of publication bias with corrected funnel 947 plots: SMD plotted against sample size-based precision estimate: (A) platelets, (B) D-dimers, 948 (C) fibrinogen, (D) activated partial thromboplastin time, (E) prothrombin time. 